\title{
Half-sandwich complexes of rhodium containing cysteine-derived ligands $\dagger$
}

María Carmona, ${ }^{\mathrm{a}}$ Ricardo Rodríguez, ${ }^{\text {a }}$ Fernando J. Lahoz, ${ }^{\mathrm{a}}$ Pilar García-Orduña, ${ }^{\mathrm{a}}$ Iñaki Osante, ${ }^{\mathrm{b}}$ Carlos Cativiela, ${ }^{\mathrm{b}}$ José A. López, ${ }^{\mathrm{a}}$ and Daniel Carmona*a

Received ......

DOI:

The modified cysteine $S$-benzyl- $\alpha$-methyl-L-cysteine (HL2) has been prepared starting from $L$-cysteine chlorhydrate. The reaction of commercial $S$-benzyl- $L$-cysteine (HL1) or HL2 with the dimer $\left[\left\{\left(\eta^{5}-\mathrm{C}_{5} \mathrm{Me}_{5}\right) \mathrm{RhCl}\right\}_{2}(\mu-\mathrm{Cl})_{2}\right]$ gives rise to the cationic complexes $\left[\left(\eta^{5}-\mathrm{C}_{5} \mathrm{Me}_{5}\right) \mathrm{RhCl}(\mathbf{H L})\right] \mathrm{Cl}$ (HL = HL1 (1), HL2 (2)) in which the cysteine ligand exhibits a $\kappa^{2} N, S$ coordination mode. In basic medium, HL1 or HL2 react with $\left[\left\{\left(\eta^{5}-\right.\right.\right.$ $\left.\left.\mathrm{C}_{5} \mathrm{Me}_{5}\right) \mathrm{RhCl}\right\}_{2}(\mu-\mathrm{Cl})_{2}$ ] affording mixtures of the two epimers at the metal centre of the neutral complexes $\left[\left(\eta^{5}-\mathrm{C}_{5} \mathrm{Me}_{5}\right) \mathrm{RhCl}\left(\kappa^{2} N, O-\mathbf{L}\right)\right](\mathbf{H L}=\mathbf{H L 1}$ (3), HL2 (4)), in which the amino carboxylate adopts a $\kappa^{2} N, O$ mode of coordination, along with variable amounts of the cationic compounds $\left[\left(\eta^{5}-\mathrm{C}_{5} \mathrm{Me}_{5}\right) \mathrm{Rh}\left(\kappa^{3} N, O, S-\mathbf{L}\right)\right] \mathrm{Cl}$ (HL = HL1 (6Cl), HL2 (7Cl)), which contain $\kappa^{3} N, O, S$ coordinated cysteine-derived ligands. However, in basic medium, the $N$-Boc substituted cysteine $S$-benzyl- $N$-Boc- $L$-cysteine (HL3) only yields the $\kappa^{2} \mathrm{O}, S$ coordinated derivative $\left[\left(\eta^{5}-\mathrm{C}_{5} \mathrm{Me}_{5}\right) \mathrm{RhCl}\left(\kappa^{2} \mathrm{O}, S-\mathbf{L} 3\right)\right](5)$ as a mixture of two diastereomers depending on the configuration at the metal centre. The bidentate chelate complexes 3-5 react with $\mathrm{AgSbF}_{6}$ rendering the hexafluoroantimonates $\left[\left(\eta^{5}\right.\right.$ $\left.\left.\mathrm{C}_{5} \mathrm{Me}_{5}\right) \operatorname{Rh}\left(\kappa^{3} N, O, S-\mathbf{L}\right)\right]\left[\mathrm{SbF}_{6}\right](\mathbf{H L}=\mathbf{H L 1}(\mathbf{6 S b}), \quad$ HL2 (7Sb), HL3 (8Sb)) with tridentate coordination. Compound $\mathbf{8 S b}$ reacts with $\mathrm{NaHCO}_{3}$ giving the neutral complex $\left[\left(\eta^{5}-\mathrm{C}_{5} \mathrm{Me}_{5}\right) \mathrm{Rh}\left(\kappa^{3} N, O, S-\mathbf{L} \mathbf{3}_{-\mathbf{H}}\right)\right](\mathbf{9})$ which can be also prepared by reacting the dimer $\left[\left\{\left(\eta^{5}-\mathrm{C}_{5} \mathrm{Me}_{5}\right) \mathrm{RhCl}\right\}_{2}(\mu-\mathrm{Cl})_{2}\right]$ with $\mathbf{H L} 3$ in the presence of two equivalents of $\mathrm{NaHCO}_{3}$. 
The new compounds contain up to four stereogenic centres, namely, Rh, S, N, and C. The absolute configuration of the complexes has been established by spectroscopic and diffractometric means including the crystal structure determination of $\left[\left(\eta^{5}-\right.\right.$ $\left.\left.\mathrm{C}_{5} \mathrm{Me}_{5}\right) \operatorname{RhCl}\left(\kappa^{2} \mathrm{O}, S-\mathbf{L} 3\right)\right] \quad(\mathbf{5}), \quad\left[\left(\eta^{5}-\mathrm{C}_{5} \mathrm{Me}_{5}\right) \mathrm{Rh}\left(\kappa^{3} N, O, S-\mathbf{L 1}\right)\right]\left[\mathrm{SbF}_{6}\right] \quad(\mathbf{6 S b}), \quad\left[\left(\eta^{5}-\right.\right.$ $\left.\left.\mathrm{C}_{5} \mathrm{Me}_{5}\right) \operatorname{Rh}\left(\kappa^{3} N, O, S-\mathbf{L} 2\right)\right]\left[\mathrm{SbF}_{6}\right](\mathbf{7 S b})$, and $\left[\left(\eta^{5}-\mathrm{C}_{5} \mathrm{Me}_{5}\right) \mathrm{Rh}\left(\kappa^{3} N, O, S-\mathbf{L} \mathbf{3}_{-\mathbf{H}}\right)\right](\mathbf{9})$. Variable temperature ${ }^{1} \mathrm{H}$ NMR studies reveal the existence of epimerization processes and theoretical calculations discriminate their nature.

${ }^{a}$ Instituto de Síntesis Química y Catálisis Homogénea (ISQCH), CSIC - Universidad de Zaragoza, Departamento de Química Inorgánica, Pedro Cerbuna 12, 50009 Zaragoza, Spain, E-mail: dcarmona@unizar.es,riromar@unizar.es

${ }^{b}$ Instituto de Síntesis Química y Catálisis Homogénea (ISQCH), CSIC - Universidad de Zaragoza, Departamento de Química Orgánica, Pedro Cerbuna 12, 50009 Zaragoza, Spain

†Electronic supplementary information (ESI) available: Kinetic data. Files containing full details of the structural analysis of complexes 6Sb, 7Sb, and 9 (CIF format). CCDC 1485794-1485796. Metallacycles characterization for complexes 6Sb, 7Sb and 9. Hydrogen bond interactions in 6Sb and 7Sb. CD spectra. Preparation of HL2 by $S$-benzylation of IV. Frequency list of all ground and transition states. Cartesian coordinates for all DFT-calculated structures (XYZ). For ESI and crystallographic data in CIF or other electronic format see DOI: 


\section{Introduction}

Amino acids are biologically relevant molecules whose coordination chemistry toward transition-metal ions has been largely investigated owing to their easy availability, versatile bonding modes and potential applications in a variety of chemical fields. ${ }^{1}$ Complexation of $\alpha$-amino acids to metallic systems gives rise to a variety of coordination modes. Thus, although for no functionalized $\alpha$-amino acids monodentate and bidentate chelate coordination are known, the latter being the prevalent one, for functionalized $\alpha$-amino acids tridentate chelate coordination modes have also been described. ${ }^{1 \mathrm{~d}, 2}$ Moreover, amino carboxylate derivatives of transition metals have found application in fields as different as asymmetric synthesis, ${ }^{1 \mathrm{a}, 3}$ bioinorganic, $^{4}$ supramolecular $^{5}$ or solid state chemistry. ${ }^{6}$

Sulphur-containing amino acids have drawn a great deal of attention due to their crucial and significant functions in biological systems. ${ }^{7}$ In particular, it has been shown that silver complexes containing cysteine or glutathione play a key role in bacterial inactivation. ${ }^{8}$ In the same line, the active sites of metalloproteins like acetyl coenzyme A synthase $^{9}$ or $[\mathrm{NiFe}]$ hydrogenase ${ }^{10}$ contain nickel ions that are coordinated exclusively by donors derived from cysteine. Very recently, Buglyó et al. have shown that the thioether containing amino acids $D$ - and $L$-methionine and $S$-methyl- $L$-cysteine coordinate to half-sandwich solvated cations of formula $\left[\left(\eta^{\mathrm{n}} \text {-ring }\right) \mathrm{M}\left(\mathrm{H}_{2} \mathrm{O}\right)_{3}\right]^{2+}\left(\left(\eta^{\mathrm{n}}-\right.\right.$ ring $) \mathrm{M}=\left(\eta^{5}-\mathrm{C}_{5} \mathrm{Me}_{5}\right) \mathrm{Rh},\left(\eta^{5}-\mathrm{C}_{5} \mathrm{Me}_{5}\right) \mathrm{Ir},\left(\eta^{6}-p-\mathrm{MeC}_{6} \mathrm{H}_{4} i \mathrm{Pr}\right) \mathrm{Ru}$ or $\left.\left(\eta^{6}-p-\mathrm{MeC}_{6} \mathrm{H}_{4} i \mathrm{Pr}\right) \mathrm{Os}\right)$ mostly in a $\kappa^{3} N, O, S$ manner. ${ }^{11}$

From a coordination point of view, cysteine behaves as a multifunctional organic ligand able to bind to a variety of metal ions through amine, carboxylate and thiolate groups to form chiral mononuclear and multinuclear complexes. ${ }^{5 b}$ In some cases, 
mixtures of products differing in coordination modes and nuclearity are obtained and the factors that govern their distribution and interconversion remain unclear. ${ }^{4 b}$

On the other hand, it is well known that the incorporation of quaternary amino acids in peptide sequences provides very useful information on their bioactive conformation and results in beneficial physiological effects. ${ }^{12}$

With all these concerns in mind, in the present paper we report on the controlled preparation of new half sandwich rhodium (III) complexes containing modified cysteines such as $S$-benzyl- $L$-cysteine (HL1), the quaternary $S$-benzyl- $\alpha$-methyl- $L$ cysteine (HL2) and the N-protected S-benzyl- $N$-Boc- $L$-cysteine (HL3) (Chart 1). Special attention will be paid to the coordination features of the employed amino acids. The chirality of the compounds is assessed and the epimerization processes that take place are studied experimentally and theoretically.

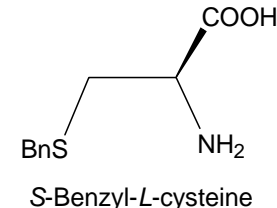

HL1

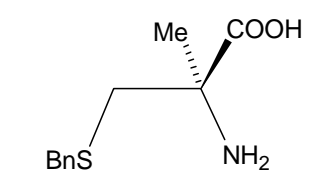

S-Benzyl- $\alpha$-methyl- $L$-cysteine

HL2

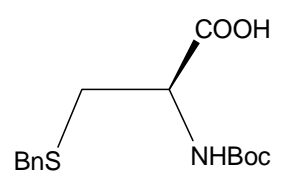

S-Benzyl-N-Boc-L-cysteine

HL3

Chart 1. Modified cysteines 


\section{Results and discussion}

\section{Cysteine-derived ligands}

Modified cysteines HL1 and HL3 (Chart 1) are commercially available. Cysteine HL2 was prepared starting from $L$-cysteine hydrochloride methyl ester according to the sequence of reactions depicted in Scheme 1 . Reaction of the $L$-cysteine hydrochloride methyl ester with pivalaldehyde affords tiazolidine $\mathbf{I}$. $N$-formylation of $\mathbf{I}$ with sodium formate renders diastereoselectively the cis methyl ester II in $83 \%$ isolated yield. Subsequent reaction with lithium diisopropyl amide (LDA), using $N, N^{\prime}-$ dimethylpropylurea (DMPU) as co-solvent, forms the corresponding enolate which trapped with methyl iodide gives rise, again diastereoselectively, to the trans tert-butyl to methyl isomer of the 4-methyl thiazolidine III. Hydrolysis of III generates $\alpha$-methylL-cysteine hydrochloride IV. ${ }^{13}$ S-benzylation of $\mathbf{I V}$, that renders HL2, was carried out by reacting IV with benzylbromide in basic medium, following a modification of the procedure described for the $S$-benzylation of $L$-cysteine by Wang et al. ${ }^{14}$ (see Electronic Supplementary Information).

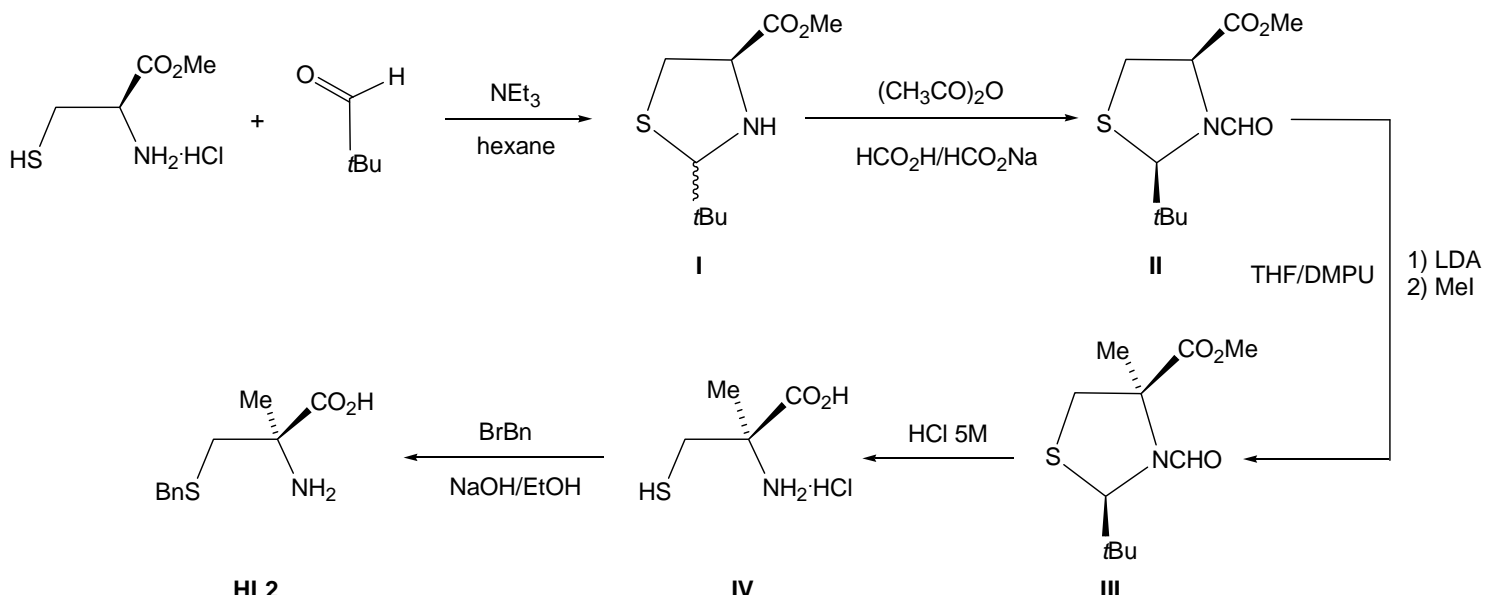

Scheme 1. Synthesis of HL2 


\section{Rhodium complexes}

Reaction of the rhodium dimer $\left[\left\{\left(\eta^{5}-\mathrm{C}_{5} \mathrm{Me}_{5}\right) \mathrm{RhCl}\right\}_{2}(\mu-\mathrm{Cl})_{2}\right]^{15}$ with $\mathbf{H L 1}$ or $\mathbf{H L} 2$ affords the cationic complexes $\left[\left(\eta^{5}-\mathrm{C}_{5} \mathrm{Me}_{5}\right) \operatorname{RhCl}\left(\kappa^{2} N, S-\mathbf{H L}\right)\right] \mathrm{Cl}(\mathbf{H L}=\mathbf{H L 1}(\mathbf{1}), \mathbf{H L 2}(\mathbf{2}))$ in high isolated yields (Scheme 2). However, the addition of the $N$-Boc protected cysteine $S$-benzyl- $N$-Boc- $L$-cysteine (HL3) to the rhodium dimer results in the formation of unidentified products in low yield.

In basic medium, HL1 and HL2 react with the rhodium dimer $\left[\left\{\left(\eta^{5}-\right.\right.\right.$ $\left.\left.\left.\mathrm{C}_{5} \mathrm{Me}_{5}\right) \mathrm{RhCl}\right\}_{2}(\mu-\mathrm{Cl})_{2}\right]$ affording neutral complexes of formula $\left[\left(\eta^{5}-\mathrm{C}_{5} \mathrm{Me}_{5}\right) \mathrm{RhCl}\left(\kappa^{2} N, O-\right.\right.$ L)] (HL = HL1 (3), HL2 (4)), in which the amino carboxylate adopts a $\kappa^{2} N$, O mode of coordination, together with variable amounts of cationic compounds of formula [( $\eta^{5}$ $\left.\left.\mathrm{C}_{5} \mathrm{Me}_{5}\right) \operatorname{Rh}\left(\kappa^{3} N, O, S-\mathbf{L}\right)\right] \mathrm{Cl}(\mathbf{H L}=\mathbf{H L 1}(\mathbf{6 C l}), \mathbf{H L} 2(\mathbf{C C l}))$, in which the amino carboxylate coordinates as tridentate $\kappa^{3} N, O, S$ ligand. ${ }^{16}$ However, in the same conditions, the metallic dimer reacts with $\mathbf{H L 3}$ yielding $\left[\left(\eta^{5}-\mathrm{C}_{5} \mathrm{Me}_{5}\right) \operatorname{RhCl}\left(\kappa^{2} O, S-\mathbf{L 3}\right)\right](5)$, with the amino carboxylate ligand adopting a $\kappa^{2} O, S$ coordination mode (Scheme 2).

Analytically pure tridentate $\kappa^{3} N, O, S$ complexes can be prepared treating $\mathbf{3}$ and $\mathbf{4}$ with 1 equiv. of $\mathrm{AgSbF}_{6}$. Analogously, reaction of the $N$-Boc cysteine complex 5 with 1 equiv. of $\mathrm{AgSbF}_{6}$ afforded the homologue compound $\mathbf{8 S b}$ with tridentate coordination (Scheme 3).

During the formation of all these complexes, the metal becomes a stereogenic centre and, therefore, stereoisomers with different configuration at the metal centre could be obtained. Additionally, when the sulphur coordinates to the metal centre (compounds 1, 2, 5-8) the inversion barrier at this atom could become high enough to render independently observable epimers at sulphur. In compound $\mathbf{8 S b}$, the nitrogen is also a stereogenic centre. 


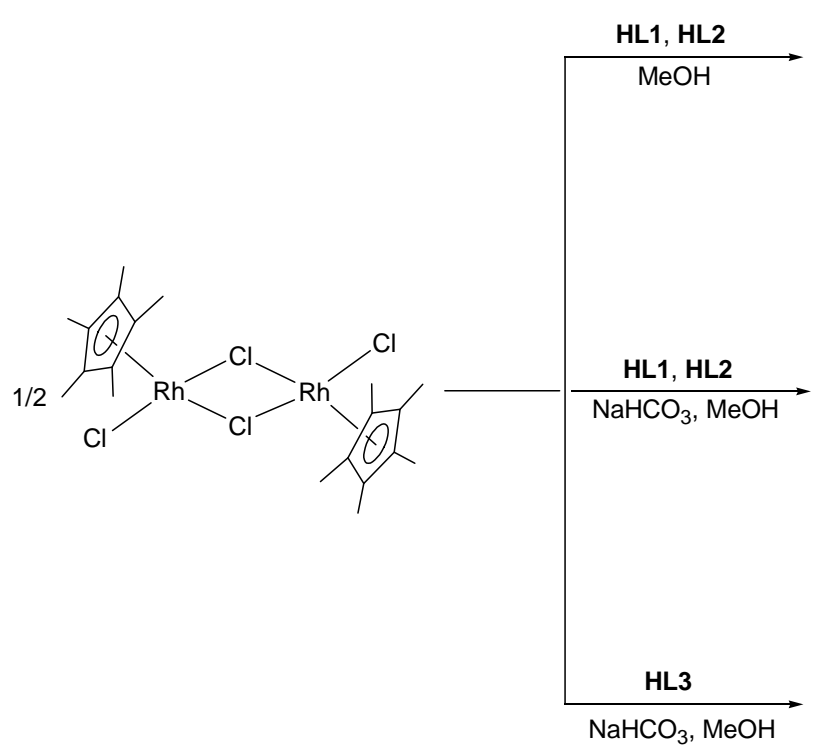

Scheme 2. Synthesis of the complexes
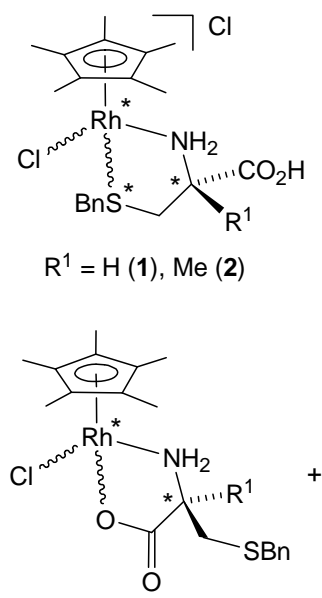

$R^{1}=H(3), M e(4)$

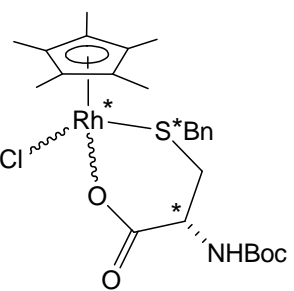

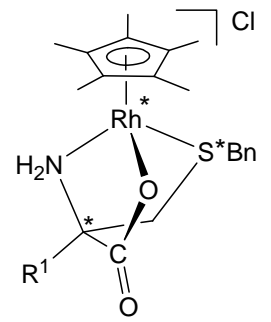

$\mathrm{R}^{1}=\mathrm{H}(6 \mathrm{Cl}), \mathrm{Me}(7 \mathrm{Cl})$
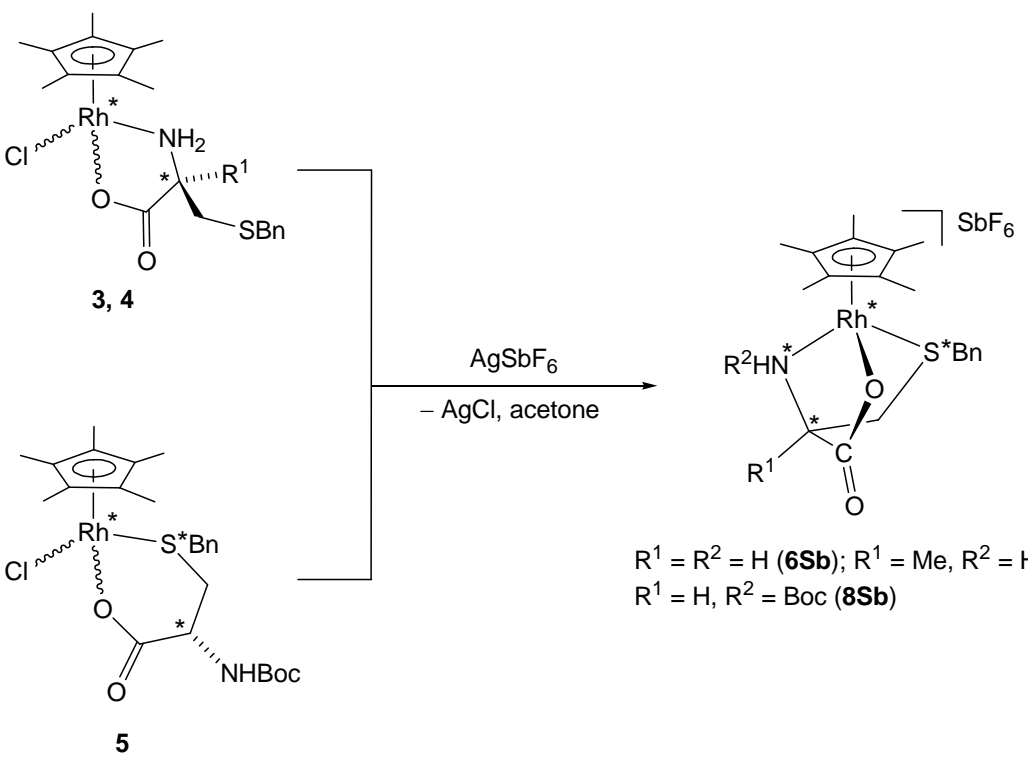

$\mathrm{R}^{1}=\mathrm{R}^{2}=\mathrm{H}(\mathbf{6 S b}) ; \mathrm{R}^{1}=\mathrm{Me}, \mathrm{R}^{2}=\mathrm{H}(\mathbf{7 S b}) ;$

$R^{1}=H, R^{2}=B o c(8 S b)$

Scheme 3. Preparation of the complexes $6 \mathbf{S b}-\mathbf{8 S b}$

In the preparative reactions, enantiopure $R$ at carbon cysteine-derived ligands were employed and as the compounds were prepared under soft conditions, it can be assumed that no racemization at carbon occurs. Regarding the number of possible stereoisomers, it is interesting to point out that in $R$ cysteines the lone electronic pairs of the sulphur 
can only attack the Si-face of the metal ion (Scheme 4) and, therefore, only $R$ at the metal centre isomers ${ }^{18}$ can be formed in complexes such as 6-8 that incorporate $\kappa^{3} N, O, S$ coordinated cysteine-based ligands. Identical diastereoselective induction has to occur in the attack of the nitrogen lone electron pair in $\kappa^{2} O, S$ coordinated intermediates to render complexes with tridentate coordination. In summary, in the tridentate $\kappa^{3} N, O, S$ cysteine-derived complexes $\mathbf{6 - 8}$, both the rhodium and the carbon exclusively present $R$ configuration. Therefore, only stereoisomers differing on the configuration at sulphur (also at nitrogen for compound $\mathbf{8 S b}$ ) can be expected.

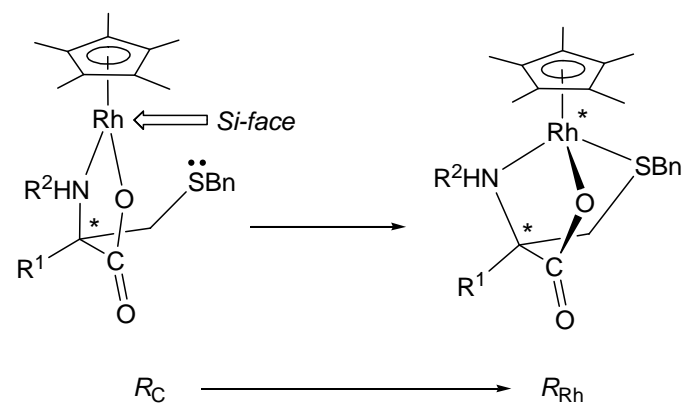

Scheme 4. Diastereoselective induction in the formation of the tridentate complexes

We will discuss the structural characterization of all the new compounds, including the assignment of their absolute configuration, in some detail later on.

Several attempts to grow single crystals of the complex $\left[\left(\eta^{5}-\mathrm{C}_{5} \mathrm{Me}_{5}\right) \mathrm{RhCl}\left(\kappa^{2} \mathrm{O}, S\right.\right.$ L3)] (5), to carry out a proper X-ray diffraction analysis, were not successful. However, a tentative data collection on a single crystal -of very limited quality- allowed us to ascertain the atom connectivity and the Rh and S configurations. ${ }^{17}$ In fact, the metal coordination results to be pseudo-octahedral. An $\eta^{5}-\mathrm{C}_{5} \mathrm{Me}_{5}$ group occupies three formal coordination positions and the $N$-Boc protected cysteine $\mathbf{L} 3$ coordinates the metal through one of the carboxylate oxygens and the sulphur atom acting as a chelate ligand. One chloride completes the coordination sphere of the metal. According to the priority sequence, ${ }^{18}$ the absolute configurations of the rhodium and sulphur were determined to be $S$. 


\section{Molecular structure of the complexes $\left(R_{\mathrm{Rh}}, S_{\mathrm{S}}, R_{\mathrm{C}}\right)-\left[\left(\eta^{5}-\mathrm{C}_{5} \mathrm{Me}_{5}\right) \mathrm{Rh}\left(\kappa^{3} N, O, S-\right.\right.$ \\ $\mathrm{L1})]\left[\mathrm{SbF}_{6}\right](6 \mathrm{Sb})$ and $\left(R_{\mathrm{Rh}}, S_{\mathrm{S}}, R_{\mathrm{C}}\right)-\left[\left(\eta^{5}-\mathrm{C}_{5} \mathrm{Me}_{5}\right) \mathrm{Rh}\left(\boldsymbol{\kappa}^{3} N, O, S-\mathrm{L} 2\right)\right]\left[\mathrm{SbF}_{6}\right](7 \mathrm{Sb})$}

Single crystals of the complexes $\mathbf{6 S b}$ and 7Sb were grown by slow diffusion of diethyl ether into methanolic solutions of diastereomeric mixtures of these compounds and the solid state molecular structures were determined by X-ray diffraction methods. Interestingly, complex 7Sb crystallizes with two different conformational isomers in the unit cell 7Sb-A and 7Sb-B, differing in the disposition of the benzyl substituent around the S-C(14) bond. In spite of this differentiation, both independent molecules of 7Sb exhibit similar bond lengths, and stereochemical features.

Figure 1 shows selected views of the cations of the molecules and representative geometrical parameters are listed in Table 1. Both complexes exhibit the so-called “three-legged piano-stool” geometry. An $\eta^{5}-\mathrm{C}_{5} \mathrm{Me}_{5}$ group occupies three fac positions and the corresponding cysteine, $S$-benzyl- $L$-cysteine (6Sb) or $S$-benzyl- $\alpha$-methyl- $L$ cysteine (7Sb), occupies the three remaining coordination sites adopting a $\kappa^{3} N, O, S$ coordination mode. According to the ligand priority sequence, ${ }^{18}$ the absolute configuration is $R_{\mathrm{Rh}}, S_{\mathrm{S}}, R_{\mathrm{C}}$ for the two compounds.

The tridentate coordination of $S$-benzyl- $L$-cysteine (6Sb) or $S$-benzyl- $\alpha$-methyl- $L$ cysteine (7Sb) leads to the formation of two five-membered, Rh-O-C-C-N and Rh-S-C$\mathrm{C}-\mathrm{N}$, and one six-membered Rh-S-C-C-C-O metallacycles with ${ }^{5} \mathrm{E} / \mathrm{T}_{1}, \mathrm{E}_{5}$ and $\mathrm{B}_{4,1}$ conformations, respectively. Similar deviations from planarity and puckering phase values have been found in both complexes (see Electronic Supplementary Information).

The solid state structure of $\mathbf{6 S b}$ and $\mathbf{7 S b}$ are stabilized by strong hydrogen bond networks established between $\mathrm{N}-\mathrm{H}$ protons and carboxylate oxygen atoms together with weak C-H $\cdots$ O hydrogen bonds (see Electronic Supplementary Information). 


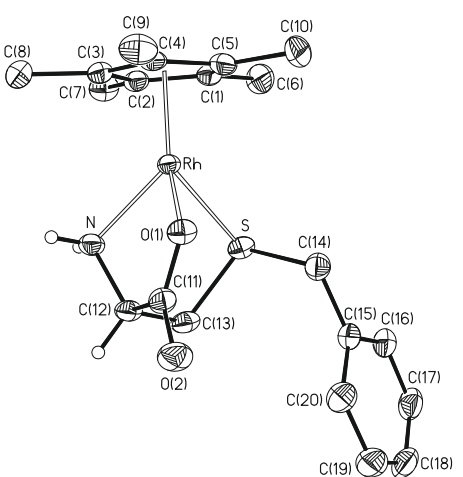

$6 \mathrm{Sb}$

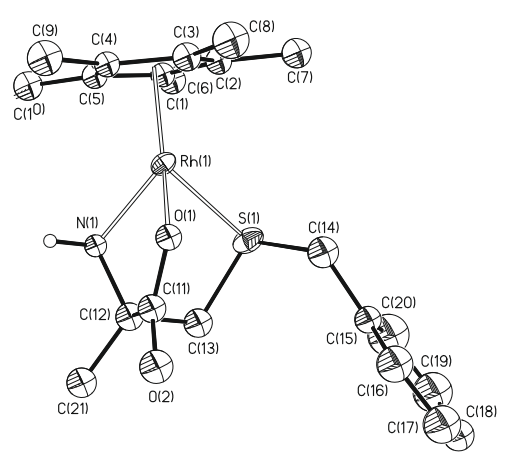

7Sb-A

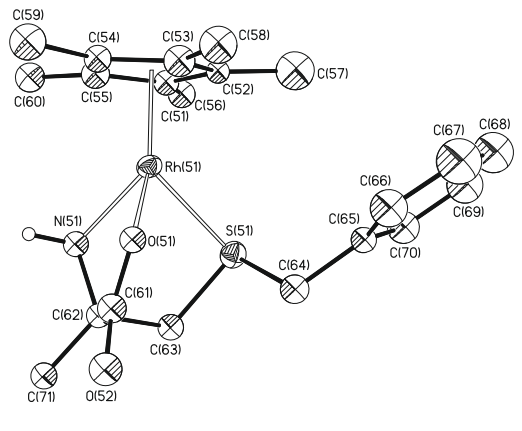

7Sb-B

Fig. 1. Molecular representation of the cations of $6 \mathrm{Sb}$ and $7 \mathrm{Sb}$.

Table 1. Selected bond distances $(\AA)$ and angles $\left(^{\circ}\right)$ for $6 \mathrm{Sb}$ y $7 \mathrm{Sb}$.

\begin{tabular}{|l|l|l|l|l|l|l|l|}
\hline & \multicolumn{1}{|c|}{ 6Sb } & \multicolumn{1}{|c|}{ 7Sb-A } & \multicolumn{1}{|c|}{ 7Sb-B } & & \multicolumn{1}{|c|}{ 6Sb } & \multicolumn{1}{|c|}{ 7Sb-A } & \multicolumn{1}{|c|}{ 7Sb-B } \\
\hline Rh-S & $2.4067(13)$ & $2.382(7)$ & $2.393(7)$ & S-Rh-O(1) & $85.57(10)$ & $85.9(5)$ & $85.3(5)$ \\
\hline Rh-N & $2.127(4)$ & $2.044(18)$ & $2.094(18)$ & S-Rh-Ct & $131.31(6)$ & $130.5(4)$ & $129.6(1)$ \\
\hline Rh-O(1) & $2.128(3)$ & $2.084(16)$ & $2.100(16)$ & N-Rh-O(1) & $76.22(15)$ & $76.9(7)$ & $75.9(7)$ \\
\hline Rh-Ct $^{\mathrm{a}}$ & $1.7637(17)$ & $1.779(11)$ & $1.772(11)$ & N-Rh-Ct & $131.93(11)$ & $132.0(7)$ & $131.7(6)$ \\
\hline S-Rh-N & $82.99(14)$ & $82.0(5)$ & $81.8(5)$ & $\mathrm{O}(1)-{\mathrm{Rh}-\mathrm{Ct}^{\mathrm{a}}}^{\mathrm{a}}$ & $129.49(9)$ & $130.4(6)$ & $132.8(6)$ \\
\hline
\end{tabular}

${ }^{\mathrm{a}} \mathrm{Ct}$ represents the centroid of the $\eta^{5}-\mathrm{C}_{5} \mathrm{Me}_{5}$ ring.

\section{Characterization of the compounds}

Besides the determination of the molecular structures above discussed, the new complexes were characterized by analytical and spectroscopic means (see Experimental Section). Assignment of the NMR signals was verified by two dimensional homonuclear and heteronuclear $\left({ }^{1} \mathrm{H}_{-}{ }^{13} \mathrm{C}\right.$ and $\left.{ }^{1} \mathrm{H}-{ }^{15} \mathrm{~N}\right)$ correlations. The IR spectra showed strong $v(C=O)$ absorptions in the $1610-1630 \mathrm{~cm}^{-1}$ range (carboxylate) and around $1760 \mathrm{~cm}^{-1}$ (Boc). ${ }^{19}$ The $\mathrm{SbF}_{6}$ derivatives present a strong band around $650 \mathrm{~cm}^{-1}$ attributed to this anion. The ${ }^{1} \mathrm{H}$ NMR data are consistent with the presence of the $\mathrm{C}_{5} \mathrm{Me}_{5}$ and cysteine ligands in a 1:1 molar ratio, in all cases.

$\left[\left(\eta^{5}-C_{5} \mathrm{Me}_{5}\right) \mathrm{RhCl}\left(\kappa^{2} \mathrm{~N}, \mathrm{~S}-\mathrm{HL}\right)\right] \mathrm{Cl}$ complexes. Complexes $\mathbf{1}$ and $\mathbf{2}$ were prepared in the absence of base. The proton of the carboxylic acid is not dissociated ( $\delta \mathrm{OH}$ centred at 8.7 ppm, in $\mathrm{CD}_{2} \mathrm{Cl}_{2}$ for complex 1) and bidentate coordination takes place through the most 
nucleophilic nitrogen and sulphur atoms of the cysteine rendering a Rh-N-C-C-S fivemembered metallacycle (Scheme 2).

In the solid state, the two epimers at the metal centre were isolated in 85/15 molar ratio in both cases. ${ }^{20}$ While, in the major isomer, the pro-S proton of the $\mathrm{NH}_{2}$ group shows a NOE relationship with the $\mathrm{C}_{5} \mathrm{Me}_{5}$ protons, in the minor isomer a NOE relationship occurs between the pro- $R$ proton and the protons of the cyclic ligand. These data indicate that the metal centre has $S$ configuration in the major isomer and $R$ in the minor one.

Only one set of signals for each epimer was observed in the ${ }^{1} \mathrm{H}$ NMR spectra from 298 to $193 \mathrm{~K}$. As the coordinated sulphur is a stereogenic centre, either it adopts only one configuration or both epimers at sulphur quickly exchange even at $193 \mathrm{~K}$.

$\left[\left(\eta^{5}-C_{5} M e_{5}\right) R h\left(\kappa^{3} N, O, S-L\right)\right]^{+}$complexes. In the cationic complexes of formula $\left[\left(\eta^{5}-\right.\right.$ $\left.\left.\mathrm{C}_{5} \mathrm{Me}_{5}\right) \mathrm{Rh}\left(\kappa^{3} N, O, S-\mathbf{L}\right)\right]^{+}(\mathbf{6 - 8})$ the cysteine adopts a $\kappa^{3} N, O, S$ coordination mode (Schemes 2 and 3) as revealed by the molecular structures of the complexes $\mathbf{6 S b}$ and 7Sb determined by diffractometric means (Figure 1).

As stated above, the configuration at rhodium as well as that at the amino acid carbon is $R$. For compounds $\mathbf{6 S b}$ and $7 \mathbf{S b}$, although at room temperature, the NMR spectra consist of only one set of signals, below $253 \mathrm{~K}$ a new set of signals was observed in a relative intensity lower than $2 \%$. We tentatively assign these isomers to the two epimers at the sulphur and, according to the solid state molecular structures, the major component would correspond to the $S$ at sulphur diastereomer. However, for compound $\mathbf{8 S b}$, only one set of signals was observed in the ${ }^{1} \mathrm{H}$ NMR spectra from 298 to $193 \mathrm{~K}$. We assume that compound $\mathbf{8 S b}$ is diastereopure. 
As expected, nitrogen coordination strongly affects ${ }^{15} \mathrm{~N}$ NMR chemical shift. Thus, while this nucleus resonates at $86.71 \mathrm{ppm}$ with respect to ${ }^{15} \mathrm{NH}_{3}$ in free $S$-benzyl- $N$-BocL-cysteine HL3, it appears at $68.28 \mathrm{ppm}$ in the metallic derivative $\mathbf{8 S \mathbf { b }}$, in which the cysteine nitrogen is coordinated to the metal centre. ${ }^{21}$ The chemical shift of the asymmetric carbon $\mathrm{C}^{*}$ is also strongly affected by the coordination of the nitrogen. Thus, for example, this carbon resonates at $53.06 \mathrm{ppm}$ in free HL3 but it appears at $62.76 \mathrm{ppm}$ in $\mathbf{8 S b}$. This strong deshielding contrasts with the shielding of about $6.3 \mathrm{ppm}$ found for the methylene carbon $\mathrm{C}^{*} \mathrm{CH}_{2} \mathrm{~S}$, adjacent to the sulphur which is also coordinated to the metal centre in $\mathbf{8 S \mathbf { b }}$. So, $\delta$ values of the asymmetric carbon and that of the methylene $\mathrm{C}^{*} \mathrm{CH}_{2} \mathrm{~S}$ are useful criteria for diagnostic the coordination of the nitrogen and sulphur atoms of the cysteine ligand, respectively.

When the cysteine-derived ligand displays a $\kappa^{3}$ coordination mode (complexes 6-8), the $\mathrm{C}_{5} \mathrm{Me}_{5}$ protons give a singlet at around $1.90 \mathrm{ppm}$, independently from which cysteine-derived ligand was involved.

At room temperature, the most significant absorption in the circular dichroism spectra of these compounds is a negative maximum in the $370-377 \mathrm{~nm}$ range. As free $\alpha$ amino acids do not show Cotton effects above $230 \mathrm{~nm},{ }^{22}$ these absorptions were tentatively assigned to transitions associated to the $R$ configuration at the metal centre.

In summary, compounds 6-8 are obtained as chlorides or hexafluoroantimonates of the epimers at sulphur of cations of formula $\left[\left(\eta^{5}-\mathrm{C}_{5} \mathrm{Me}_{5}\right) \mathrm{Rh}\left(\kappa^{3} N, O, S-\mathbf{L}\right)\right]^{+}$in which the amino carboxylates act as tridentate ligands. The configuration of the major isomer of the hexafluoroantimonates $\mathbf{6 S b - 8 S b}(\geq 98 \%)$ is $R_{\mathrm{Rh}}, S_{\mathrm{S}}, R_{\mathrm{C}}$.

$\left[\left(\eta^{5}-C_{5} M e_{5}\right) R h C l\left(\kappa^{2} N, O-L\right)\right]$ complexes. According to NMR data, the neutral complexes $\left[\left(\eta^{5}-\mathrm{C}_{5} \mathrm{Me}_{5}\right) \mathrm{RhCl}\left(\kappa^{2} N, O-\mathbf{L}\right)\right](3,4)$ are in equilibrium with the corresponding cationic chlorides $\left[\left(\eta^{5}-\mathrm{C}_{5} \mathrm{Me}_{5}\right) \mathrm{Rh}\left(\kappa^{3} N, O, S-\mathbf{L}\right)\right] \mathrm{Cl}(\mathbf{6 C l}, \mathbf{7 C l})$ in which the chloride has 
been replaced from the metal coordination sphere by the sulphur atom. Changing the tertiary $\mathbf{L} \mathbf{1}$ by the quaternary $\mathbf{L} \mathbf{2}$ cysteine-based ligand, the amount of the compound with tridentate coordination increases from 11 to $42 \%$, in chloroform, and from 56 to $85 \%$, in the more polar solvent methanol. In solution, the two epimers at the metal atom of the compounds $\mathbf{3}$ and $\mathbf{4}$ were detected. The concentration of the complex with tridentate coordination also increases as temperature increases but the molar ratio between the two epimers at the metal centre remains constant. As the tridentate coordination can only be achieved from the $R_{\mathrm{Rh}}, R_{\mathrm{C}}$ epimer (Scheme 4 ), the equilibria depicted in Scheme 5 have to operate, i. e., to increase the concentration of the complex with tridentate coordination, the $S$ at the metal centre isomer has to epimerize to the $R$ at the metal centre isomer, to maintain constant the molar ratio of epimers at the metal. In fact, ROESY experiments clearly establish the existence of exchange between the two epimers at the metal centre as well as between the $R$ at the metal centre isomers and the corresponding complexes $\left[\left(\eta^{5}-\mathrm{C}_{5} \mathrm{Me}_{5}\right) \mathrm{Rh}\left(\kappa^{3} N, O, S-\mathbf{L}\right)\right]^{+}$.

In good agreement with their neutral nature, the $\mathrm{C}_{5} \mathrm{Me}_{5}$ protons of the bidentate cysteine complexes 3 and $\mathbf{4}$ give a singlet at around $1.60 \mathrm{ppm}$, about $0.3 \mathrm{ppm}$ shielded with respect to the cationic complexes 6-8 with tridentate coordination.

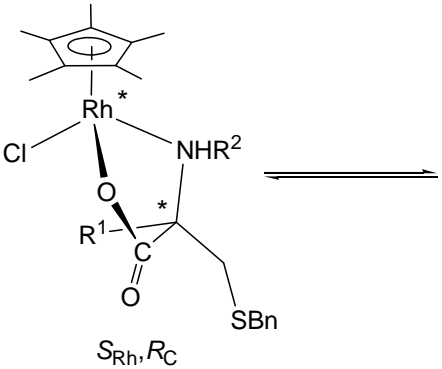

3, 4

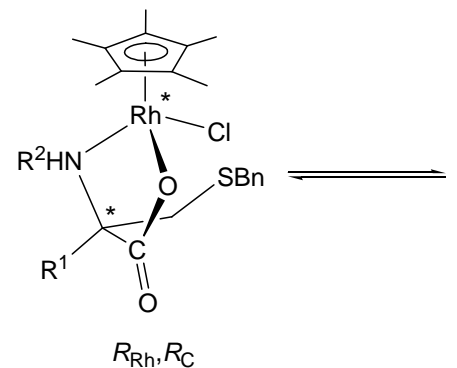

$R_{\mathrm{Rh}}, R_{\mathrm{C}}$

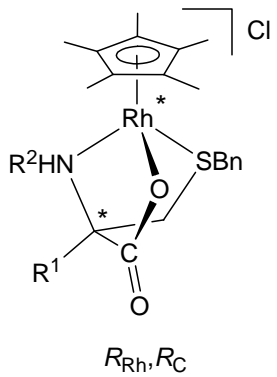

$6 \mathrm{Cl}, 7 \mathrm{Cl}$

Scheme 5. Equilibria between 3 and 4 and the cationic tridentate chlorides $6 \mathrm{Cl}$ and $7 \mathrm{Cl}$ 
In the major bidentate epimer, irradiation of the proton or Me bonded to the asymmetric carbon originates enhancement for the $\mathrm{C}_{5} \mathrm{Me}_{5}$ protons. This NOE effect indicates that the configuration of the metal centre in the major epimers is $R$.

In summary, the reaction of the dimer $\left[\left\{\left(\eta^{5}-\mathrm{C}_{5} \mathrm{Me}_{5}\right) \mathrm{RhCl}\right\}_{2}(\mu-\mathrm{Cl})_{2}\right]$ with cysteines HL1 and HL2, in the presence of $\mathrm{NaHCO}_{3}$, renders equilibrium mixtures of the two epimers at the metal centre of the $\kappa^{2} N, O-\mathbf{L}$ complexes $\left(R_{\mathrm{Rh}}, R_{\mathrm{C}}\right.$ and $\left.S_{\mathrm{Rh}}, R_{\mathrm{C}}\right)-\left[\left(\eta^{5}-\right.\right.$ $\left.\left.\mathrm{C}_{5} \mathrm{Me}_{5}\right) \operatorname{RhCl}\left(\kappa^{2} N, O-\mathbf{L}\right)\right](3,4)$ with the corresponding $\kappa^{3} N, O, S$ compounds $\left[\left(\eta^{5}-\right.\right.$ $\left.\left.\mathrm{C}_{5} \mathrm{Me}_{5}\right) \mathrm{Rh}\left(\kappa^{3} N, O, S-\mathbf{L}\right)\right] \mathrm{Cl}(\mathbf{6 C l}, \mathbf{7 C l})$, mostly as $R_{\mathrm{Rh}}, S_{\mathrm{S}}, R_{\mathrm{C}}$ diastereomers (Scheme 2).

The $\left[\left(\eta^{5}-C_{5} M e_{5}\right) R h C l\left(\kappa^{2} O, S-L 3\right)\right]$ complex. When the dimer $\left[\left\{\left(\eta^{5}-\mathrm{C}_{5} \mathrm{Me}_{5}\right) \mathrm{RhCl}\right\}_{2}(\mu\right.$ $\left.\mathrm{Cl})_{2}\right]$ reacts with the cysteine $\mathbf{H L 3}$, in the presence of $\mathrm{NaHCO}_{3}$, the complex $\left[\left(\eta^{5}-\right.\right.$ $\left.\left.\mathrm{C}_{5} \mathrm{Me}_{5}\right) \mathrm{RhCl}\left(\kappa^{2} \mathrm{O}, \mathrm{S}-\mathbf{L} 3\right)\right]$ (5) was isolated. At room temperature, the NMR spectrum of the isolated solid shows the presence of the two epimers at the metal centre in $97 / 3$ molar ratio. ${ }^{20}$ The molecular structure, determined by X-ray diffraction methods (see above), establishes that the configuration at the rhodium in the major epimer is $S$. According to this structural determination, the chemical shift of the nitrogen (89.85 ppm, major isomer) and asymmetric carbon $C^{*}$ (50.65, 50.59 ppm, major and minor isomers, respectively) indicate that the nitrogen is not coordinated to the metal centre. The chemical shift of the $\mathrm{C}_{5} \mathrm{Me}_{5}$ protons, around $1.60 \mathrm{ppm}$, corresponds to a chelate bidentate coordination for the cysteine.

At low temperature (below $233 \mathrm{~K}$ ) traces of a third isomer were detected that were tentatively assigned to the epimer at sulphur of the $S$ at Rh isomer.

\section{Deprotonation of the complex $\left(R_{\mathrm{Rh}}, S_{\mathrm{S}}, R_{\mathrm{C}}\right)-\left[\left(\eta^{5}-\mathrm{C}_{5} \mathrm{Me}_{5}\right) \mathrm{Rh}\left(\kappa^{3} N, O, S-\mathrm{L} 3\right)\right]\left[\mathrm{SbF}_{6}\right](8 \mathrm{Sb})$}

Reaction of the complex $\mathbf{8 S b}$ with $\mathrm{NaHCO}_{3}$ gave the neutral amiduro complex $\left[\left(\eta^{5}-\right.\right.$ $\left.\left.\mathrm{C}_{5} \mathrm{Me}_{5}\right) \mathrm{Rh}\left(\kappa^{3} N, O, S-\mathbf{L} 3_{-\mathbf{H}}\right)\right]$ (9). Complex 9 can be also prepared by treating the dimer 
$\left[\left\{\left(\eta^{5}-\mathrm{C}_{5} \mathrm{Me}_{5}\right) \mathrm{RhCl}\right\}_{2}(\mu-\mathrm{Cl})_{2}\right]$ with the cysteine $\mathbf{H L} 3$ in the presence of 2 equivalents of $\mathrm{NaHCO}_{3}$ (Scheme 6).

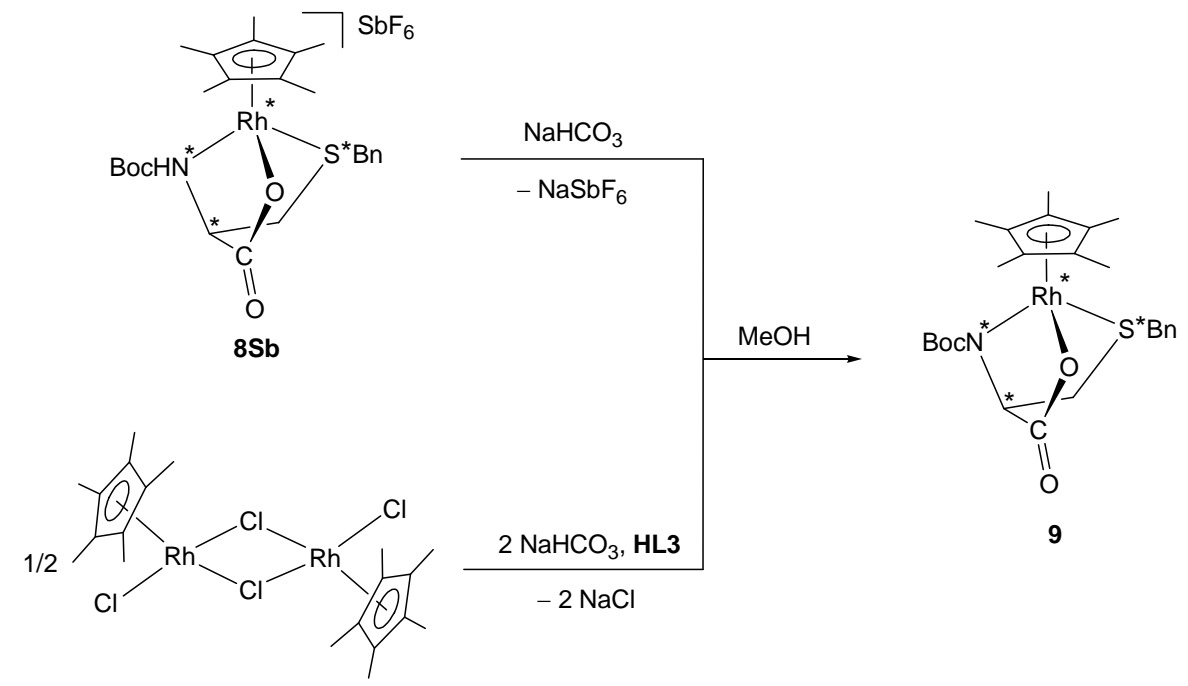

Scheme 6. Preparation of complex 9

In complex 9, the chemical shift of the asymmetric carbon (67.72 ppm) and that of the $\mathrm{C}_{5} \mathrm{Me}_{5}$ protons $(1.90 \mathrm{ppm})$ suggest that the nitrogen is coordinated to the metal centre and that the cysteine-derived ligand retains its $\kappa^{3} N, O, S$ coordination mode. A negative maximum centred at $342 \mathrm{~nm}$ in the circular dichroism spectrum is attributed to the $R$ at the metal centre configuration (see above). All these data were corroborated by the determination of its crystal structure by X-ray diffractometry.

A molecular representation of the complex is depicted in Figure 2 and selected geometrical parameters are summarized in Table 2. The coordination around the rhodium is pseudo-octahedral. An $\eta^{5}-\mathrm{C}_{5} \mathrm{Me}_{5}$ group occupies three formal coordination positions while the $N$-Boc protected cysteine $\mathbf{L} 3$ coordinates the metal centre through one of the carboxylate oxygens and through the sulphur and nitrogen atoms. As expected the absolute configuration of the rhodium is $R$. The benzyl substituent at sulphur occupies a pseudoaxial position in the six-membered metallacycle Rh-O-C-CC-S, the resulting configuration at sulphur being $S$. Comparison of the solid state 


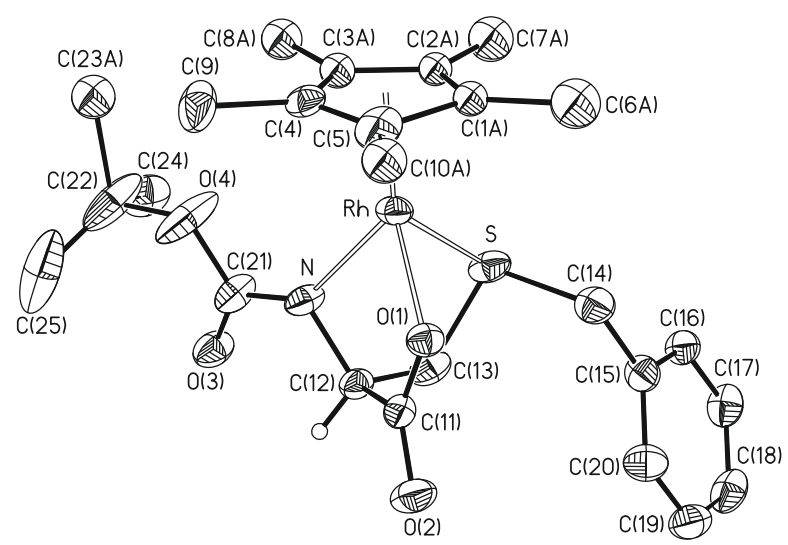

Fig. 2. Molecular representation of complex $\mathbf{9}$.

Table 2. Selected bond distances $(\AA)$ and angles $\left(^{\circ}\right)$ for 9.

\begin{tabular}{|l|l|l|l|}
\hline Rh-S & $2.4337(13)$ & S-Rh-Ct & $128.80(17)$ \\
\hline Rh-N & $2.093(5)$ & N-Rh-O(1) & $78.42(15)$ \\
\hline Rh-O(1) & $2.094(3)$ & N-Rh-Ct & $134.6(2)$ \\
\hline Rh-Ct $^{\mathrm{a}}$ & $1.761(6)$ & $\mathrm{O}(1)-\mathrm{Rh}^{\mathrm{a}} \mathrm{Ct}^{\mathrm{a}}$ & $130.1(2)$ \\
\hline $\mathrm{N}-\mathrm{C}(21)$ & $1.337(7)$ & $\mathrm{Rh}-\mathrm{N}-\mathrm{C}(12)$ & $103.7(3)$ \\
\hline $\mathrm{N}-\mathrm{C}(12)$ & $1.467(6)$ & $\mathrm{Rh}-\mathrm{N}-\mathrm{C}(21)$ & $138.1(4)$ \\
\hline $\mathrm{S}-\mathrm{Rh}-\mathrm{N}$ & $80.24(13)$ & $\mathrm{C}(12)-\mathrm{N}-\mathrm{C}(21)$ & $115.1(4)$ \\
\hline S-Rh-O(1) & $85.62(10)$ & & \\
\hline
\end{tabular}

${ }^{\text {a }} \mathrm{Ct}$ represents the centroid of the $\eta^{5}-\mathrm{C}_{5} \mathrm{Me}_{5}$ ring.

structure of 9 with those of the cationic complexes $6 \mathbf{S b}$ and $7 \mathrm{Sb}$ reveals that the conformation of the metallacycles is identical, although smaller deviations from planarity are found in the Rh-O-C-C-N and Rh-S-C-C-N metallacycles in 9 (see Electronic Supplementary Information). The geometry of the deprotonated $\mathrm{N}$ atom is almost trigonal planar as evidenced by the sum of the Rh-N-C and C-N-C angles (356.9(6) $)^{\circ}$ close to $360^{\circ}$. This fact can be accounted for by assuming delocalization of the nitrogen electron pair due to the presence of a conjugated CO double bond. In fact, the N-C(21) bond (1.337(7) $\AA$ ) exhibits some double bond character.

At $298 \mathrm{~K}$, the proton and carbon NMR spectra of complex 9 consist of only one set of sharp peaks. As the nitrogen and the sulphur atoms are stereogenic centres, a variable temperature NMR study in the range 298 - 183K was undertaken, in methanol- $\mathrm{d}_{4}$. The singlet attributed to the $t \mathrm{Bu}$ substituent of the Boc, which resonates at $1.41 \mathrm{ppm}$ at 298 
K, was taken as reference. On cooling, this singlet broadens out, coalesces at about 243 $\mathrm{K}$ and splits into two differently populated signals (60/40 ratio) below $235 \mathrm{~K}$. The low temperature limiting spectrum was achieved at $193 \mathrm{~K}$. The process obeys a first-order rate law, with derived activation parameters at $293 \mathrm{~K}$ of $\Delta \mathrm{H}^{\#}=-0.56 \pm 0.03 \mathrm{kcal} \cdot \mathrm{mol}^{-1}$, $\Delta \mathrm{S}^{\#}=-44.3 \pm 5.6 \mathrm{cal} \cdot \mathrm{mol}^{-1} \cdot \mathrm{K}^{-1}$ and $\Delta \mathrm{G}^{\#}=12.43 \pm 1.62 \mathrm{kcal} \cdot \mathrm{mol}^{-1}$ (see Electronic Supplementary Information).

The experimentally observed NMR features strongly indicate that an epimerization process, at nitrogen or at sulphur, is taking place. Epimerization at one of the two stereocentres is frozen at low temperature but the other quickly epimerizes even at 183 K. Trying to discriminate the behaviour of these two stereocentres, theoretical calculations were performed by DFT methods.

The geometry of complex $\mathbf{9}$ was optimized on the basis of the determined solid structure (see above). According to the almost planar environment around the nitrogen, DFT calculations showed a very low transition state for the epimerization process at this atom. Therefore, the kinetic data measured for the fluxional rearrangement observed must correspond to the epimerization process at sulphur. Moreover, the negative value, experimentally found, for the activation entropy strongly suggested an associative process. Taking into account the experimental NMR conditions, the most plausible pathway would involve the coordination of a methanol molecule. Besides, the whole process must comprise the rotation of the benzyl group around the $\mathrm{C}(13)-\mathrm{S}$ bound, facilitated by decoordination of the sulphur atom. So, the modelled process consists of: decoordination of sulphur, methanol coordination at the subsequently generated vacant, rotation of the benzyl group, methanol decoordination and, finally, sulphur recoordination with opposite configuration. 
The calculated pathway is shown in Scheme 7. A methanol molecule is present from $\mathrm{m} 1$ to $\mathrm{m} 4$ models, as van der Waals complexes in $\mathrm{m} 1$ and $\mathrm{m} 4$ and as a coordinated ligand in $\mathrm{m} 2$ and $\mathrm{m} 3$. The most energetically demanding single step is the first one, 8.7 $\mathrm{kcal} \cdot \mathrm{mol}^{-1}$, mainly accounting for the cleavage of the Rh-S bond but also for the interaction with the solvent. Next step is coordination of methanol through the ts12 transition state, with a relative free energy of $9.7 \mathrm{kcal} \cdot \mathrm{mol}^{-1}$. The resulting methanol solvated complex presents a free energy of $6.0 \mathrm{kcal} \cdot \mathrm{mol}^{-1}$. The transition structure for the rotation of the benzyl group, ts23, shows a free energy of $10.3 \mathrm{kcal} \mathrm{mol}^{-1}$, being the

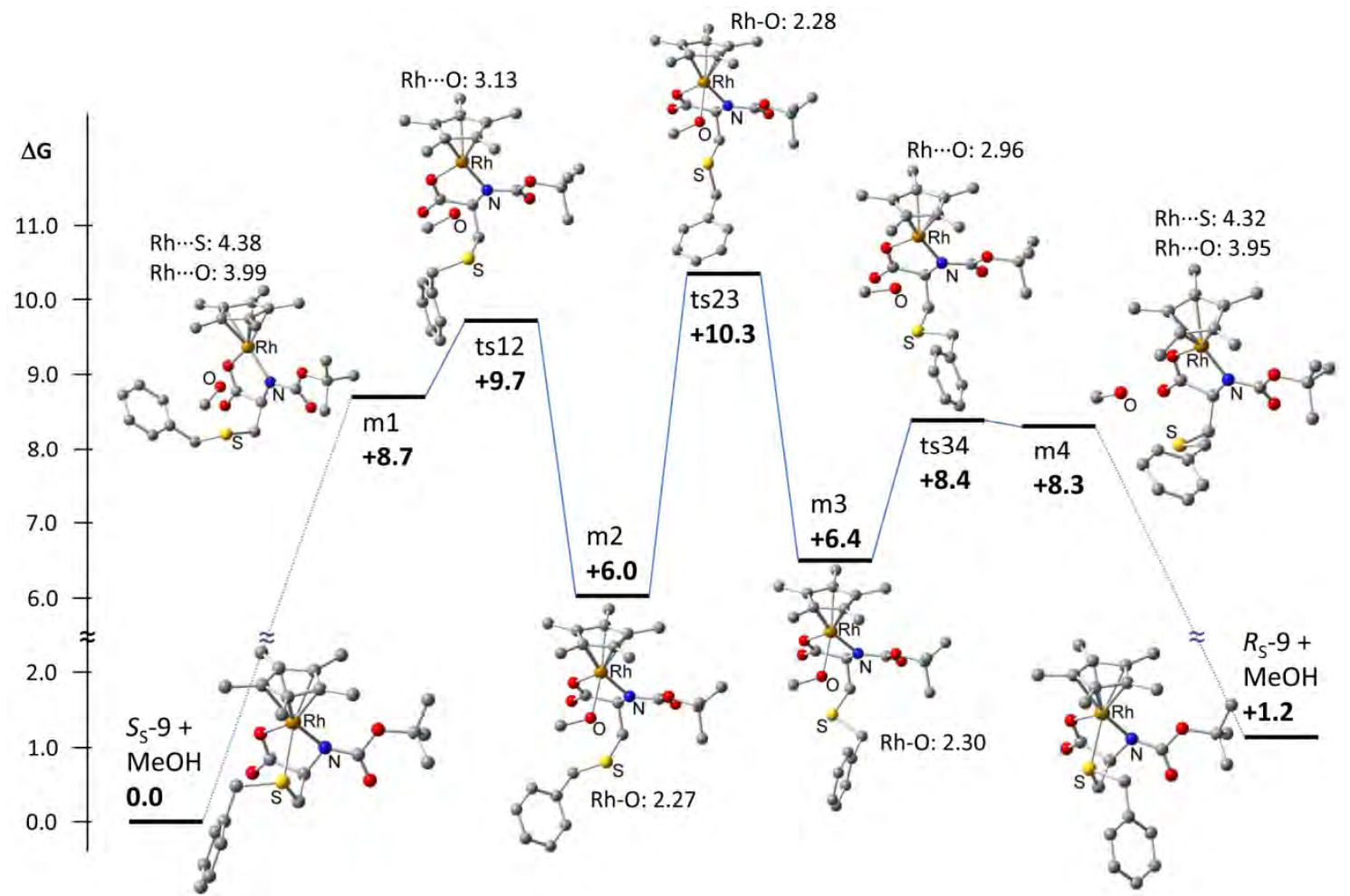

Scheme 7. Reaction profiles and relative free energies $(\mathrm{kcal} / \mathrm{mol})$ for the epimerization of complex 9, computed at the DFT level including PCM solvent $(\mathrm{MeOH})$ corrections

activation barrier of the whole process. The methanol decoordination step proceeds through the transition state ts34 that presents a relative free energy of $8.4 \mathrm{kcal} \mathrm{mol}^{-1}$. The $R$ at sulphur epimer is slightly less stable than the $S$ isomer $\left(1.2 \mathrm{kcal} \mathrm{mol}^{-1}\right)$. Finally, the calculated activation parameters: $\Delta \mathrm{H}=-2.2 \mathrm{kcal} \cdot \mathrm{mol}^{-1}, \Delta \mathrm{S}=-42.1 \mathrm{cal} \cdot \mathrm{mol}^{-1} \cdot \mathrm{K}^{-1}$ and $\Delta \mathrm{G}=10.3 \mathrm{kcal} \cdot \mathrm{mol}^{-1}$ are in good agreement with the experimental results. In summary, 
DFT calculations support that the observed fluxional process in $\mathbf{9}$ is the epimerization at sulphur.

\section{Conclusions}

The richness of the rhodium coordination chemistry that modified cysteines can display is shown. Examples of neutral $\kappa^{2} N, S$, monoanionic $\kappa^{2} N, O, \kappa^{2} S, O$ and $\kappa^{3} N, O, S$, as well as, dianionic $\kappa^{3} N, O, S$ coordination modes are described (Scheme 8). The $N$-Boc cysteine HL3 can be considered as a hemilabile ligand due to the low coordination capability of the protected nitrogen.

The new complexes contain up to four stereogenic centres. From spectroscopic, theoretical and crystallographic data, the absolute configuration of the compounds has been established. The coordination features of the complexes bring about a high level of stereoselectivity. Thus, for example, only tricoordinate complexes in which the metal centre and the asymmetric carbon of the cysteine-based ligand have the same configuration can be formed. The ratio of epimers at sulphur is governed by the steric hindrance between the $\mathrm{C}_{5} \mathrm{Me}_{5}$ and benzyl moieties. Only small amounts (if any) of the most strained epimer were detected. Epimerization processes were observed. In particular, for compound $\mathbf{9}$, theoretical calculations discriminate between epimerization at nitrogen or at sulphur.

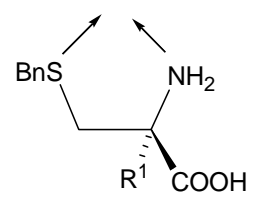

$k^{2} N, S$

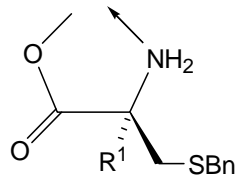

$\kappa^{2} N, O$

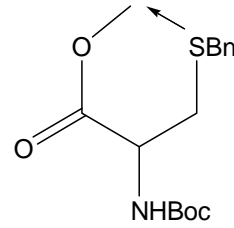

$\kappa^{2} O, S$

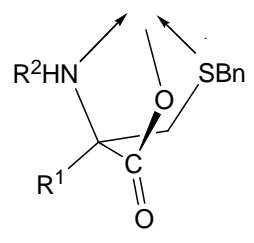

$\kappa^{3} N, O, S$

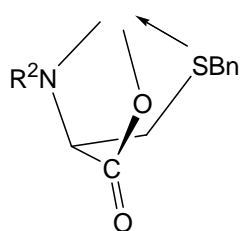

${ }_{k}^{3} \mathrm{~N}, \mathrm{O}, \mathrm{S}$

Scheme 8. Coordination modes of the cysteine-derived ligands 


\section{Experimental Section}

\section{General information}

All preparations have been carried out under argon. All solvents were treated in a PS400-6 Innovative Technologies Solvent Purification System (SPS) and degassed prior to use. Infrared spectra were recorded on Perkin-Elmer Spectrum-100 (ATR mode) FT-IR spectrometer. Carbon, hydrogen, nitrogen and sulphur analyses were performed using a Perkin-Elmer $240 \mathrm{~B}$ microanalyzer. ${ }^{1} \mathrm{H}$ and ${ }^{13} \mathrm{C}$ spectra were recorded on a Bruker AV300 (300.13 MHz), a Bruker AV-400 (400.16 MHz) or a Bruker AV-500 (500.13 $\mathrm{MHz}$ ) spectrometers. In both, ${ }^{1} \mathrm{H}$ NMR and ${ }^{13} \mathrm{C}$ NMR measurements the chemical shifts are expressed in ppm downfield from $\mathrm{SiMe}_{4} . J$ values are given in Hz. COSY, NOESY, HSQC, HMQC, and HMBC ${ }^{1} \mathrm{H}-\mathrm{X}\left(\mathrm{X}={ }^{1} \mathrm{H},{ }^{13} \mathrm{C}\right)$ correlation spectra were obtained using standard procedures. CD spectra were determined in acetone (ca. $4 \times 10^{-4} \mathrm{~mol} \mathrm{~L}^{-1}$ solutions) in a $1 \mathrm{~cm}$ path length cell by using a JASCO J-810 spectropolarimeter. Mass spectra were obtained with a Micro Tof-Q Bruker Daltonics spectrometer. Rhodium trichloride was purchased from Johnson Matthey. Cysteines HL1 and HL3 are commercially available from Acros and Aldrich, respectively.

Preparation of the complexes $\left[\left(\eta^{5}-\mathrm{C}_{5} \mathrm{Me}_{5}\right) \mathrm{RhCl}\left(\kappa^{2} N, S-\mathrm{HL}\right)\right] \mathrm{Cl},(\mathrm{HL}=\mathrm{HL} 1(1), \mathrm{HL} 2$ (2))

At room temperature, to a suspension of the dimer $\left[\left\{\left(\eta^{5}-\mathrm{C}_{5} \mathrm{Me}_{5}\right) \mathrm{RhCl}\right\}_{2}(\mu-\mathrm{Cl})_{2}\right](100.0$ $\mathrm{mg}, 0.16 \mathrm{mmol}$ ), in $10 \mathrm{~mL}$ of $\mathrm{MeOH}, 0.32 \mathrm{mmol}$ of the corresponding cysteine-derived ligand were added. The resulting orange solution was stirred for $1 \mathrm{~h}$ and then was filtered to remove any insoluble material. The solution was concentrated under reduced pressure to ca. $1 \mathrm{~mL}$. The slow addition of $\mathrm{Et}_{2} \mathrm{O}$ led to the precipitation of an orange solid which was washed with $\mathrm{Et}_{2} \mathrm{O}(3 \times 5 \mathrm{~mL})$ and vacuum-dried. 
[( $\left.\left.\eta^{5}-\mathbf{C}_{5} \mathbf{M e}_{5}\right) \mathbf{R h C l}\left(\kappa^{2} N, S-H L 1\right)\right] C l$ (1). Yield: $95 \%$. Diastereomeric ratio: 85/15. Anal. calcd for $\mathrm{C}_{20} \mathrm{H}_{28} \mathrm{Cl}_{2} \mathrm{NO}_{2} \mathrm{RhS} \cdot 2 \mathrm{H}_{2} \mathrm{O},{ }^{23}$ \%: C, 44.62; H, 5.62; N, 2.60; S, 5.96. Found, \%: C, 44.58; H, 6.00; N, 2.56; S, 6.11. IR (solid, $\mathrm{cm}^{-1}$ ): $v(\mathrm{OH}) 2909$ (vbr), $v(\mathrm{C}=\mathrm{O}) 1719$ (s).

$S_{\mathrm{Rh}}, R_{\mathrm{C}}$ diastereomer (85 \%). ${ }^{1} \mathrm{H} \mathrm{NMR}\left(500.13 \mathrm{MHz}, \mathrm{CD}_{2} \mathrm{Cl}_{2}, 298 \mathrm{~K}, \mathrm{ppm}\right): \delta 9.7$ - 7.75 (br, 1H, OH), $7.65-7.20\left(2 \times \mathrm{m}, 5 \mathrm{H}, \mathrm{H}_{\mathrm{Ar}}\right), 6.16$ (pt, $\left.J=10.0 \mathrm{~Hz}, 1 \mathrm{H}, \mathrm{NH}\right), 4.58$ (AB

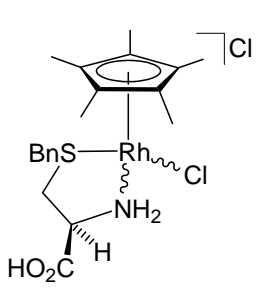
system, $J=11.4 \mathrm{~Hz}, 2 \mathrm{H}, \mathrm{CH}_{2} \mathrm{Ph}$ ), 4.22 (brs, 1H, NH), 4.04 (m, 1H, $\left.\mathrm{C}^{*} \mathrm{H}\right), 3.54\left(\mathrm{ABXX}{ }^{\prime}\right.$ system, $J_{\mathrm{AB}}=13.9, J_{\mathrm{AX}}=10.7, J_{\mathrm{AX}}=3.6 \mathrm{~Hz}, 2 \mathrm{H}$, $\mathrm{CH}_{2} \mathrm{C}^{*}$ ), 1.62 (s, 15H, $\left.\mathrm{C}_{5} \mathrm{Me}_{5}\right) .{ }^{13} \mathrm{C}\left\{{ }^{1} \mathrm{H}\right\} \mathrm{NMR}\left(125.8 \mathrm{MHz}, \mathrm{CD}_{2} \mathrm{Cl}_{2}, 298\right.$ $K, p p m): \delta 170.35(\mathrm{C}=\mathrm{O}), 133.77,131.05,129.02,128.81\left(6 \mathrm{C}, \mathrm{C}_{\mathrm{Ar}}\right), 98.84\left(\mathrm{~d}, J_{\mathrm{RhC}}=7.7\right.$ $\left.\mathrm{Hz}, 5 \mathrm{C}, \mathrm{C}_{5} \mathrm{Me}_{5}\right), 58.82\left(\mathrm{C}^{*}\right), 40.60\left(\mathrm{CH}_{2} \mathrm{Ph}\right), 38.62\left(\mathrm{CH}_{2} \mathrm{C}^{*}\right), 9.12\left(5 \mathrm{C}, \mathrm{C}_{5} \mathrm{Me}_{5}\right)$.

$R_{\mathrm{Rh}}, R_{\mathrm{C}}$ diastereomer (15\%). ${ }^{1} \mathrm{H} \mathrm{NMR}\left(500.13 \mathrm{MHz}, \mathrm{CD}_{2} \mathrm{Cl}_{2}, 298 \mathrm{~K}, \mathrm{ppm}\right): \delta 9.70-7.75$ (m, 1H, OH), $7.65-7.20\left(2 \times \mathrm{m}, 5 \mathrm{H}, \mathrm{H}_{\mathrm{Ar}}\right), 6.36$ (brs, 1H, NH), 4.33 (AB system, $J=$ $\left.12.2 \mathrm{~Hz}, 2 \mathrm{H}, \mathrm{CH}_{2} \mathrm{Ph}\right), 3.80\left(\mathrm{~m}, 2 \mathrm{H}, \mathrm{C}^{*} \mathrm{H}, \mathrm{NH}\right), 3.27$ (ABXX' system, $J_{\mathrm{AB}}=12.9, J_{\mathrm{AX}}=$ 12.0, $\left.J_{\mathrm{AX}},=3.6 \mathrm{~Hz}, 2 \mathrm{H}, \mathrm{CH}_{2} \mathrm{C}^{*}\right), 1.69\left(\mathrm{~s}, 15 \mathrm{H}, \mathrm{C}_{5} \mathrm{Me}_{5}\right) .{ }^{13} \mathrm{C}\left\{{ }^{1} \mathrm{H}\right\}$ NMR $(125.8 \mathrm{MHz}$, $\left.\mathrm{CD}_{2} \mathrm{Cl}_{2}, 298 \mathrm{~K}, \mathrm{ppm}\right): \delta 170.65(\mathrm{C}=\mathrm{O}), 133.53,130.60,129.24,128.81\left(6 \mathrm{C}, \mathrm{C}_{\mathrm{Ar}}\right), 99.15$ $\left(\mathrm{d}, J_{\mathrm{RhC}}=7.7 \mathrm{~Hz}, 5 \mathrm{C}, C_{5} \mathrm{Me}_{5}\right), 58.64\left(\mathrm{C}^{*}\right), 39.55\left(\mathrm{CH}_{2} \mathrm{Ph}\right), 38.06\left(\mathrm{CH}_{2} \mathrm{C}^{*}\right), 9.41(5 \mathrm{C}$, $\left.\mathrm{C}_{5} \mathrm{Me}_{5}\right)$

[( $\left.\left.\eta^{5}-\mathrm{C}_{5} \mathbf{M e}_{5}\right) \mathbf{R h C l}\left(\boldsymbol{\kappa}^{2} N, S-H L 2\right)\right] C l$ (2). Yield: $85 \%$. Diastereomeric ratio: 85/15. Anal. calcd for $\mathrm{C}_{21} \mathrm{H}_{30} \mathrm{Cl}_{2} \mathrm{NO}_{2} \mathrm{RhS} \cdot 3 \mathrm{H}_{2} \mathrm{O}$, \%: C, 42.87; H, 6.17; N, 2.38; S, 5.45. Found, \%: C, 42.66; H, 5.93; N, 2.28; S, 5.27. IR (solid, $\left.\mathrm{cm}^{-1}\right)$ : v(OH) 2969 (vbr), v(C=O) 1734 (s).

$S_{\mathrm{Rh}}, R_{\mathrm{C}}$ diastereomer (85 \%). ${ }^{1} \mathrm{H} N \mathrm{NMR}\left(500.13 \mathrm{MHz}, \mathrm{CD}_{3} \mathrm{OD}, 298 \mathrm{~K}, \mathrm{ppm}\right): \delta 7.60-7.38$ $\left(2 \times \mathrm{m}, 5 \mathrm{H}, \mathrm{H}_{\mathrm{Ar}}\right), 5.22$ (brd, $\left.J=10.6 \mathrm{~Hz}, 1 \mathrm{H}, \mathrm{NH}\right), 4.42$ (AB system, $J=11.7 \mathrm{~Hz}, 2 \mathrm{H}$, CH $\mathrm{CH}_{2} \mathrm{Ph}$ ), 4.06 (brd, $\left.J=10.6 \mathrm{~Hz}, 1 \mathrm{H}, \mathrm{NH}\right), 3.52$ (m, 1H, $\mathrm{CH}_{2} \mathrm{C}^{*}$ ), 2.60 (d, $J=11.7 \mathrm{~Hz}$, 


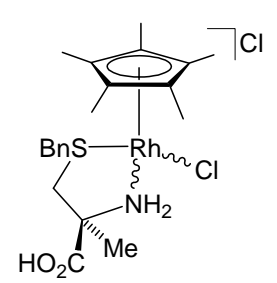

$1 \mathrm{H}, \mathrm{CH}_{2} \mathrm{C}^{*}$ ), 1.70 (brs, $3 \mathrm{H}, \mathrm{C}^{*} \mathrm{Me}$ ), 1.61 (s, $\left.\left.15 \mathrm{H}, \mathrm{C}_{5} \mathrm{Me}_{5}\right) .{ }^{13} \mathrm{C}^{1} \mathrm{H}\right\}$ NMR (125.8 MHz, $\left.C D_{3} \mathrm{OD}, 298 \mathrm{~K}, \mathrm{ppm}\right): \delta 172.12(\mathrm{C}=\mathrm{O}), 133.61$, 130.31, 128.78, $128.56\left(6 \mathrm{C}, \mathrm{C}_{\mathrm{Ar}}\right), 98.79\left(\mathrm{~d}, J_{\mathrm{RhC}}=7.8 \mathrm{~Hz}, 5 \mathrm{C}, C_{5} \mathrm{Me}_{5}\right)$, $64.22\left(\mathrm{C}^{*}\right), 44.03\left(\mathrm{CH}_{2} \mathrm{Ph}\right), 39.75\left(\mathrm{CH}_{2} \mathrm{C}^{*}\right), 25.41\left(\mathrm{C}^{*} \mathrm{Me}\right), 7.63(5 \mathrm{C}$, $\left.\mathrm{C}_{5} M e_{5}\right)$.

$R_{\mathrm{Rh}}, R_{\mathrm{C}}$ diastereomer (15\%). ${ }^{1} \mathrm{H} \mathrm{NMR}\left(500.13 \mathrm{MHz}, \mathrm{CD}_{3} \mathrm{OD}, 298 \mathrm{~K}, \mathrm{ppm}\right): \delta 7.60-7.38$ ( $2 \times \mathrm{m}, 5 \mathrm{H}, \mathrm{H}_{\mathrm{Ar}}$ ), 5.36 (brd, $\left.J=10.8 \mathrm{~Hz}, 1 \mathrm{H}, \mathrm{NH}\right), 5.12$ (brd, $J=10.8 \mathrm{~Hz}, 1 \mathrm{H}, \mathrm{NH}$ ), 4.54 (AB system, $\left.J=11.8 \mathrm{~Hz}, 2 \mathrm{H}, \mathrm{CH}_{2} \mathrm{Ph}\right), 3.52\left(\mathrm{~m}, 1 \mathrm{H}, \mathrm{CH}_{2} \mathrm{C}^{*}\right), 2.70(\mathrm{~d}, J=11.7 \mathrm{~Hz}$, $1 \mathrm{H}, \mathrm{CH}_{2} \mathrm{C}^{*}$ ), 1.70 (brs, 3H, C ${ }^{*} \mathrm{Me}$ ), 1.66 (s, $\left.15 \mathrm{H}, \mathrm{C}_{5} \mathrm{Me}_{5}\right) .{ }^{13} \mathrm{C}\left\{{ }^{1} \mathrm{H}\right\} \mathrm{NMR}(125.8 \mathrm{MHz}$, $\left.C D_{3} \mathrm{OD}, 298 \mathrm{~K}, \mathrm{ppm}\right): \delta 172.62(\mathrm{C}=\mathrm{O}), 133.52,130.16,128.82,128.60$ (6C, $\left.\mathrm{C}_{\mathrm{Ar}}\right), 98.95$ $\left(\mathrm{d}, J_{\mathrm{RhC}}=7.8 \mathrm{~Hz}, 5 \mathrm{C}, C_{5} \mathrm{Me}_{5}\right), 64.40\left(\mathrm{C}^{*}\right), 44.06\left(\mathrm{CH}_{2} \mathrm{Ph}\right), 39.44\left(\mathrm{CH}_{2} \mathrm{C}^{*}\right), 25.50$ $\left(\mathrm{C}^{*} \mathrm{Me}\right), 7.93\left(5 \mathrm{C}, \mathrm{C}_{5} M e_{5}\right)$.

Preparation of the complexes $\left[\left(\eta^{5}-\mathrm{C}_{5} \mathrm{Me}_{5}\right) \mathrm{RhCl}\left(\kappa^{2} N, O-\mathrm{L}\right)\right](\mathrm{L}=\mathrm{L} 1$ (3), L2 (4), L3 (5)) and $\left[\left(\eta^{5}-\mathrm{C}_{5} \mathrm{Me}_{5}\right) \mathrm{Rh}\left(\kappa^{3} N, O, S-\mathrm{L}\right)\right] \mathrm{Cl}(\mathrm{L}=\mathrm{L} 1(6 \mathrm{Cl}), \mathrm{L} 2(7 \mathrm{Cl}))$

At room temperature, to a suspension of the dimer $\left[\left\{\left(\eta^{5}-\mathrm{C}_{5} \mathrm{Me}_{5}\right) \mathrm{RhCl}\right\}_{2}(\mu-\mathrm{Cl})_{2}\right](200.1$ $\mathrm{mg}, 0,32 \mathrm{mmol}$ ), in $10 \mathrm{~mL}$ of $\mathrm{MeOH}, 0.64 \mathrm{mmol}$ of the corresponding cysteine-derived ligand were added. The resulting orange solution was stirred for 15 min and then 64.7 $\mathrm{mg}(0.77 \mathrm{mmol})$ of $\mathrm{NaHCO}_{3}$ were added. The suspension was vigorously stirred for $2 \mathrm{~h}$ and then concentrated in vacuum until dryness. The residue was extracted with $\mathrm{CH}_{2} \mathrm{Cl}_{2}$ $(4 \times 5 \mathrm{~mL})$ and the resulting solution was concentrated under reduced pressure to $c a .3$ $\mathrm{mL}$. The slow addition of $n$-hexane led to the precipitation of an orange solid which was washed with $n$-hexane $(4 \times 5 \mathrm{~mL})$ and vacuum-dried. The solid was spectroscopically characterized as a mixture of the compounds $\mathbf{3}$ and $\mathbf{6 C l}$ (90\% yield) or $\mathbf{4}$ and $\mathbf{7 C l}$ (70\% yield). For the ligand LH3 the product was pure complex 5 (92\%, isolated yield). Mixtures of $\mathbf{3}$ and $\mathbf{6 C l}$, of similar composition, but in lower yield, were obtained as 
follows: to a suspension of $\left[\left(\eta^{5}-\mathrm{C}_{5} \mathrm{Me}_{5}\right) \mathrm{RhCl}(\mathrm{acac})\right](200.0 \mathrm{mg}, 0.54 \mathrm{mmol})$, in $10 \mathrm{~mL}$ of $\mathrm{MeOH}, 114.3 \mathrm{mg}$ (0.54 mmol) of HL1 were added. The suspension was vigorously stirred for $24 \mathrm{~h}$ and then was concentrated under reduced pressure to $c a .3 \mathrm{~mL}$. The slow addition of $n$-hexane led to the precipitation of an orange solid which was washed with n-hexane $(3 \times 10 \mathrm{~mL})$ and vacuum-dried.

[( $\left.\left.\eta^{5}-\mathbf{C}_{5} \mathbf{M e}_{5}\right) \mathbf{R h C l}\left(\kappa^{2} N, O-L 1\right)\right](3)$. Yield: $79 \%$. Isomeric ratio: 92/8. Anal. ${ }^{24}$ calcd for $\mathrm{C}_{20} \mathrm{H}_{27} \mathrm{ClNO}_{2} \mathrm{RhS} \cdot 3 \mathrm{H}_{2} \mathrm{O}$, \%: C, 44.66; H, 6.18; N, 2.60; S, 5.96. Found, \%: C, 45.06; H, 6.19; N, 2.67; S, 5.49. IR (solid, $\mathrm{cm}^{-1}$ ): v(C=O) 1612 (s).

$R_{\mathrm{Rh}}, R_{\mathrm{C}}$ diastereomer (92 \%). ${ }^{1} \mathrm{H} \mathrm{NMR}\left(300.13 \mathrm{MHz}, \mathrm{CDCl}_{3}, 298 \mathrm{~K}, \mathrm{ppm}\right): \delta 7.60-7.24$ $\left(2 \times \mathrm{m}, 5 \mathrm{H}, \mathrm{H}_{\mathrm{Ar}}\right), 5.52(\mathrm{br}, 1 \mathrm{H}, \mathrm{NH}), 4.51\left(\mathrm{AB}\right.$ system, $\left.J_{\mathrm{AB}}=11.3 \mathrm{~Hz}, 2 \mathrm{H}, \mathrm{CH}_{2} \mathrm{Ph}\right), 4.14$ (br, $1 \mathrm{H}, \mathrm{NH}), 3.82\left(\mathrm{brs}, 1 \mathrm{H}, \mathrm{C}^{*} \mathrm{H}\right), 3.50\left(\mathrm{ABX}\right.$ system, $J_{\mathrm{AB}}=12.5 \mathrm{~Hz}, J_{\mathrm{AX}}$
$128.48\left(6 \mathrm{C}, \mathrm{C}_{\mathrm{Ar}}\right), 98.31\left(\mathrm{~d}, J_{\mathrm{RhC}}=7.7 \mathrm{~Hz}, 5 \mathrm{C}, \mathrm{C}_{5} \mathrm{Me}_{5}\right), 60.29\left(\mathrm{C}^{*}\right), 40.48$ $\left(\mathrm{CH}_{2} \mathrm{C}^{*}\right), 39.07\left(\mathrm{CH}_{2} \mathrm{Ph}\right), 8.86\left(5 \mathrm{C}, \mathrm{C}_{5} \mathrm{Me}_{5}\right)$.

$S_{\mathrm{Rh}}, R_{\mathrm{C}}$ diastereomer (8 \%). ${ }^{1} \mathrm{H} N \mathrm{NMR}\left(300.13 \mathrm{MHz}, \mathrm{CDCl}_{3}, 298 \mathrm{~K}, \mathrm{ppm}\right): \delta 3.82$ (overlapped, 1H, C ${ }^{*} \mathrm{H}$ ), 3.37 (ABX system, $J_{\mathrm{AB}}=11.8 \mathrm{~Hz}, J_{\mathrm{AX}}=10.0 \mathrm{~Hz}, 2 \mathrm{H}, \mathrm{CH}_{2} \mathrm{C}^{*}$ ), 1.65 (brs, $\left.15 \mathrm{H}, \mathrm{C}_{5} \mathrm{Me}_{5}\right) .{ }^{13} \mathrm{C}\left\{{ }^{1} \mathrm{H}\right\} \mathrm{NMR}\left(125.8 \mathrm{MHz}, \mathrm{CDCl}_{3}, 298 \mathrm{~K}, \mathrm{ppm}\right): \delta 98.53$ (overlapped, 5C, $\left.C_{5} \mathrm{Me}_{5}\right), 60.04\left(\mathrm{C}^{*}\right), 41.25\left(\mathrm{CH}_{2} \mathrm{C}^{*}\right), 39.90\left(\mathrm{CH}_{2} \mathrm{Ph}\right), 9.15\left(5 \mathrm{C}, \mathrm{C}_{5} \mathrm{Me}_{5}\right)$. $\left[\left(\boldsymbol{\eta}^{5}-\mathbf{C}_{5} \mathbf{M e}_{5}\right) \mathbf{R h}\left(\boldsymbol{\kappa}^{3} \boldsymbol{N}, \boldsymbol{O}, \boldsymbol{S}-\mathbf{L 1}\right)\right] \mathrm{Cl}(\mathbf{6 C l}) . R_{\mathrm{Rh}}, R_{\mathrm{C}}$ diastereomer $(11 \%) .{ }^{1} H$ NMR $(300.13$

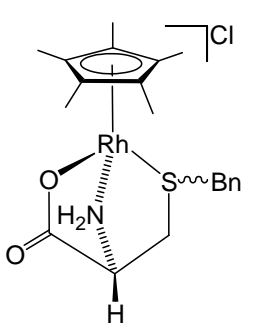
$\left.\mathrm{MHz}, \mathrm{CDCl}_{3}, 298 \mathrm{~K}, \mathrm{ppm}\right): \delta 4.32\left(\mathrm{~d}, J=12.0 \mathrm{~Hz}, 1 \mathrm{H}, \mathrm{CH}_{2} \mathrm{Ph}\right), 4.09$ (overlapped, $1 \mathrm{H}, \mathrm{CH}_{2} \mathrm{Ph}$ ), 3.48 (overlapped, $1 \mathrm{H}, \mathrm{CH}_{2} \mathrm{C}^{*}$ ), 4.03 (brs, $1 \mathrm{H}$, $\left.\mathrm{C}^{*} \mathrm{H}\right), 2.38$ (d, $J=13.7 \mathrm{~Hz}, 1 \mathrm{H}, \mathrm{CH}_{2} \mathrm{C}^{*}$ ), 1.84 (brs, 15H, $\mathrm{C}_{5} \mathrm{Me}_{5}$ ). ${ }^{13} C\left\{{ }^{1} \mathrm{H}\right\} \operatorname{NMR}\left(125.8 \mathrm{MHz}, \mathrm{CDCl}_{3}, 298 \mathrm{~K}, \mathrm{ppm}\right): \delta 96.89\left(\mathrm{~d}, J_{\mathrm{RhC}}=7.8\right.$ 
Hz, 5C, $\left.C_{5} \mathrm{Me}_{5}\right), 60.21\left(\mathrm{C}^{*}\right), 39.68\left(\mathrm{CH}_{2} \mathrm{Ph}\right), 32.42\left(\mathrm{CH}_{2} \mathrm{C}^{*}\right), 9.43\left(5 \mathrm{C}, \mathrm{C}_{5} \mathrm{Me}_{5}\right)$.

[( $\left.\left.\eta^{5}-\mathbf{C}_{5} \mathbf{M e}_{5}\right) \mathbf{R h C l}\left(\boldsymbol{\kappa}^{2} \boldsymbol{N}, \boldsymbol{O}-\mathbf{L} 2\right)\right]$ (4). Yield: $41 \%$. Isomeric ratio: 98/2. Anal. calcd for $\mathrm{C}_{21} \mathrm{H}_{29} \mathrm{ClNO}_{2} \mathrm{RhS} \cdot 3 \mathrm{H}_{2} \mathrm{O}$, \%: C, 45.70; H, 6.39; N, 2.54; S, 5.81. Found, \%: C, 45.48; H, 5.97; N, 2.39; S, 5.81. IR (solid, $\left.\mathrm{cm}^{-1}\right): v(\mathrm{C}=\mathrm{O}) 1630$ (s).

$R_{\mathrm{Rh}}, R_{\mathrm{C}}$ diastereomer (98 \%). ${ }^{1} \mathrm{H} \mathrm{NMR}\left(500.13 \mathrm{MHz}, \mathrm{CDCl}_{3}, 298 \mathrm{~K}, \mathrm{ppm}\right): \delta 7.51,7.37$ (2 × m, 5H, $\left.\mathrm{H}_{\mathrm{Ar}}\right), 5.60$ (brd, $\left.J=8.3 \mathrm{~Hz}, 1 \mathrm{H}, \mathrm{NH}\right), 4.50\left(\mathrm{AB}\right.$ system, $J_{\mathrm{AB}}=11.4 \mathrm{~Hz}, 2 \mathrm{H}$,

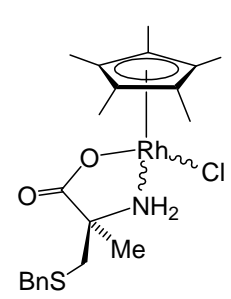
$\mathrm{CH}_{2} \mathrm{Ph}$ ), 3.88 (AB system, $J_{\mathrm{AB}}=10.8 \mathrm{~Hz}, 2 \mathrm{H}, \mathrm{CH}_{2} \mathrm{C}^{*}$ ), 3.29 (brd, $J=8.3$ $\mathrm{Hz}, 1 \mathrm{H}, \mathrm{NH}), 1.63$ (brs, 3H, C ${ }^{*} \mathrm{Me}$ ), 1.61 (s, $\left.\left.15 \mathrm{H}, \mathrm{C}_{5} \mathrm{Me}_{5}\right) .{ }^{13} \mathrm{C}^{1} \mathrm{H}\right\} \mathrm{NMR}$ (125.8 MHz, $\left.\mathrm{CDCl}_{3}, 298 \mathrm{~K}, \mathrm{ppm}\right): \delta 171.51(\mathrm{C}=\mathrm{O}), 133.48,130.82$, 128.86, $128.75\left(6 \mathrm{C}, \mathrm{C}_{\mathrm{Ar}}\right), 98.76\left(\mathrm{~d}, J_{\mathrm{RhC}}=7.6 \mathrm{~Hz}, 5 \mathrm{C}, C_{5} \mathrm{Me}_{5}\right), 66.29$ $\left(\mathrm{C}^{*}\right), 46.47\left(\mathrm{CH}_{2} \mathrm{C}^{*}\right), 39.41\left(\mathrm{CH}_{2} \mathrm{Ph}\right), 28.01\left(\mathrm{C}^{*} \mathrm{Me}\right), 9.05$ (5C, $\left.\mathrm{C}_{5} \mathrm{Me}_{5}\right)$.

$\left[\left(\boldsymbol{\eta}^{5}-\mathbf{C}_{5} \mathbf{M e}_{5}\right) \mathbf{R h}\left(\boldsymbol{\kappa}^{3} \boldsymbol{N}, \boldsymbol{O}, \mathbf{S}-\mathbf{L} 2\right)\right] \mathbf{C l}(\mathbf{7 C l}) . R_{\mathrm{Rh}}, R_{\mathrm{C}}$ diastereomer (29\%). ${ }^{1} \mathrm{H}$ NMR (500.13

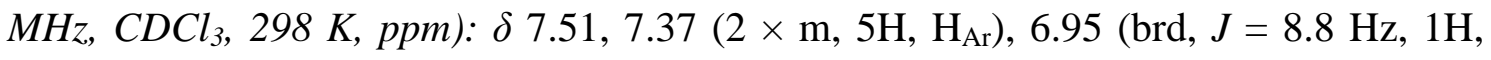
$\mathrm{NH}$ ), 5.35 (brd, $J=8.8 \mathrm{~Hz}, 1 \mathrm{H}, \mathrm{NH}$ ), 3.90 (AB system, $J_{\mathrm{AB}}=12.7 \mathrm{~Hz}, 2 \mathrm{H}, \mathrm{CH}_{2} \mathrm{Ph}$ ), $3.55\left(\mathrm{AB}\right.$ system, $J_{\mathrm{AB}}=13.9 \mathrm{~Hz}, 2 \mathrm{H}, \mathrm{CH}_{2} \mathrm{C}^{*}$ ), 1.90 (s, 15H, C ${ }_{5} \mathrm{Me}_{5}$ ), 1.63 (brs, 3H,

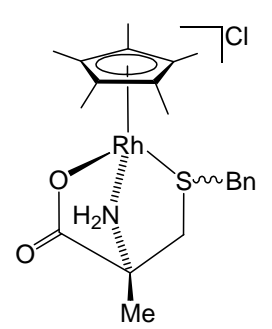
$\left.\mathrm{C}^{*} \mathrm{Me}\right) .{ }^{13} \mathrm{C}\left\{{ }^{1} \mathrm{H}\right\} \mathrm{NMR}\left(125.8 \mathrm{MHz}, \mathrm{CDCl}_{3}, 298 \mathrm{~K}, \mathrm{ppm}\right): \delta 178.51$ $(\mathrm{C}=\mathrm{O}), 132.82,130.29,129.17,128.79\left(6 \mathrm{C}, \mathrm{C}_{\mathrm{Ar}}\right), 98.86\left(\mathrm{~d}, J_{\mathrm{RhC}}=7.6\right.$ $\left.\mathrm{Hz}, 5 \mathrm{C}, \mathrm{C}_{5} \mathrm{Me}_{5}\right), 65.71\left(\mathrm{C}^{*}\right), 39.41\left(\mathrm{CH}_{2} \mathrm{Ph}\right), 36.80\left(\mathrm{CH}_{2} \mathrm{C}^{*}\right), 24.13$ $\left(\mathrm{C}^{*} \mathrm{Me}\right), 9.67$ (5C, $\left.\mathrm{C}_{5} M e_{5}\right)$.

$S_{\mathrm{Rh}}, R_{\mathrm{C}}$ diastereomer (2 \%). ${ }^{1} \mathrm{H} N \mathrm{NM}\left(500.13 \mathrm{MHz}, \mathrm{CDCl}_{3}, 298 \mathrm{~K}, \mathrm{ppm}\right): \delta 4.40(\mathrm{~d}, J=$ $11.5 \mathrm{~Hz}, 1 \mathrm{H}, \mathrm{CH}_{2} \mathrm{Ph}$ ), 4.01 (d, $J=11.5 \mathrm{~Hz}, 1 \mathrm{H}, \mathrm{CH}_{2} \mathrm{Ph}$ ), 3.90 (overlapped, $1 \mathrm{H}, \mathrm{CH}_{2} \mathrm{C}^{*}$ ), $2.31\left(\mathrm{~d}, J=10.8 \mathrm{~Hz}, 1 \mathrm{H}, \mathrm{CH}_{2} \mathrm{C}^{*}\right.$ ), 1.65 (s, $1 \mathrm{H}, \mathrm{C}^{*} \mathrm{Me}$ ), 1.56 (s, 15H, $\mathrm{C}_{5} \mathrm{Me}_{5}$ ). 
[( $\left.\left.\eta^{5}-\mathbf{C}_{5} \mathbf{M e}_{5}\right) \mathbf{R h C l}\left(\boldsymbol{\kappa}^{2} \boldsymbol{O}, \boldsymbol{S}-\mathbf{L} 3\right)\right]$ (5). Yield: $92 \%$. Isomeric ratio: 97/3. Anal. calcd for $\mathrm{C}_{25} \mathrm{H}_{35} \mathrm{ClNO}_{4} \mathrm{RhS}$, \%: C, 51.40; H, 5.99; N, 2.40; S, 5.48. Found, \%: C, 50.91; H, 6.43; N, 2.46; S, 5.63. IR (solid, $\left.\mathrm{cm}^{-1}\right): v\left(\mathrm{C}=\mathrm{O}_{\mathrm{Boc}}\right) 1757$ (s), $v(\mathrm{C}=\mathrm{O}) 1620$ (s).

$S_{\mathrm{Rh}}, R_{\mathrm{C}}$ diastereomer (97 \%). ${ }^{1} \mathrm{H} \mathrm{NMR}\left(300.13 \mathrm{MHz}, \mathrm{CDCl}_{3}, 298 \mathrm{~K}, \mathrm{ppm}\right): \delta 7.61,7.32$ $\left(2 \times \mathrm{m}, 5 \mathrm{H}, \mathrm{H}_{\mathrm{Ar}}\right), 6.08(\mathrm{br}, 1 \mathrm{H}, \mathrm{NH}), 4.83\left(\mathrm{AB}\right.$ system, $\left.J_{\mathrm{AB}}=12.2 \mathrm{~Hz}, 2 \mathrm{H}, \mathrm{CH}_{2} \mathrm{Ph}\right), 4.29$

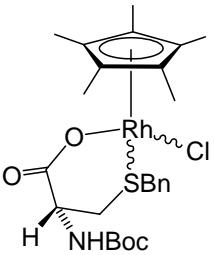
(br, $\left.1 \mathrm{H}, \mathrm{C}^{*} \mathrm{H}\right), 3.21\left(\mathrm{AB}\right.$ part, $\mathrm{ABX}$ system, $J_{\mathrm{AB}}=12.1 \mathrm{~Hz}, J_{\mathrm{AX}}=1.8 \mathrm{~Hz}$, 2H, $\mathrm{CH}_{2} \mathrm{C}^{*}$ ), 1.44 (s, 15H, $\mathrm{C}_{5} \mathrm{Me}_{5}$ ), 1.41 (s, 9H, $\left.\mathrm{Me}_{t \mathrm{Bu}}\right) .{ }^{13} C\left\{{ }^{1} \mathrm{H}\right\} N M R$ (75.47 MHz, $\left.\mathrm{CDCl}_{3}, 298 \mathrm{~K}, \mathrm{ppm}\right): \delta 175.12(\mathrm{C}=\mathrm{O}), 155.09\left(\mathrm{C}=\mathrm{O}_{\mathrm{Boc}}\right)$, 134.34, 131.13, 128.58, 128.19 (6C, $\mathrm{C}_{\mathrm{Ar}}$ ), 96.98 (d, $\left.J_{\mathrm{RhC}}=8.2 \mathrm{~Hz}, 5 \mathrm{C}, C_{5} \mathrm{Me}_{5}\right), 79.05$ $\left(\mathrm{C}_{t \mathrm{Bu}}\right), 50.65\left(\mathrm{C}^{*}\right), 38.83\left(\mathrm{CH}_{2} \mathrm{Ph}\right), 34.70\left(\mathrm{CH}_{2} \mathrm{C}^{*}\right), 28.42$ (3C, $\left.\mathrm{Me}_{t \mathrm{Bu}}\right), 8.52$ (5C, $\left.\mathrm{C}_{5} \mathrm{Me}_{5}\right)$. $R_{\mathrm{Rh}}, R_{\mathrm{C}}$ diastereomer (3 \%). ${ }^{1} \mathrm{H} \mathrm{NMR}$ (300.13 MHz, $\left.\mathrm{CDCl}_{3}, 298 \mathrm{~K}, \mathrm{ppm}\right): \delta 4.64$ (br, $1 \mathrm{H}$, $\mathrm{CH}_{2} \mathrm{Ph}$ ), 4.38 (br, 1H, C ${ }^{*} \mathrm{H}$ ), 3.87 (br, 1H, $\mathrm{CH}_{2} \mathrm{Ph}$ ), 2.66 (br, 1H, $\mathrm{CH}_{2} \mathrm{C}^{*}$ ), 2.24 (overlapped, $1 \mathrm{H}, \mathrm{CH}_{2} \mathrm{C}^{*}$ ), 1.61 (s, $15 \mathrm{H}, \mathrm{C}_{5} \mathrm{Me}_{5}$ ), 1.38 (s, 9H, $\mathrm{Me}_{t \mathrm{Bu}}$ ). ${ }^{13} C\left\{{ }^{1} \mathrm{H}\right\} N M R$ (75.47 MHz, $\mathrm{CDCl}_{3}, 298 \mathrm{~K}, \mathrm{ppm}$ ): $\delta 50.59\left(\mathrm{C}^{*}\right.$ ), 39.53 (brs, $\mathrm{CH}_{2} \mathrm{Ph}$ ), 36.20 (brs, $\mathrm{CH}_{2} \mathrm{C}^{*}$ ), 28.79 (3C, $\left.\mathrm{Me}_{t \mathrm{Bu}}\right), 8.37\left(5 \mathrm{C}, \mathrm{C}_{5} \mathrm{Me}_{5}\right)$.

Preparation of the complexes $\left[\left(\eta^{5}-\mathrm{C}_{5} \mathrm{Me}_{5}\right) \mathrm{Rh}\left(\kappa^{3} N, O, S-\mathrm{L}\right)\right]\left[\mathrm{SbF}_{6}\right](\mathrm{L}=\mathrm{L1}(6 \mathrm{Sb}), \mathrm{L} 2$ (7Sb), L3 (8Sb))

To a solution of mixtures of $\mathbf{3}$ and $\mathbf{6 C l}$ or $\mathbf{4}$ and $\mathbf{7 C l}$ or pure $\mathbf{5}(0.25 \mathrm{mmol})$ in $10 \mathrm{~mL}$ of acetone, $85.9 \mathrm{mg}(0.25 \mathrm{mmol})$ of $\mathrm{AgSbF}_{6}$ were added. After stirring for $1 \mathrm{~h}$, the AgCl formed was filtered off and the solution was concentrated under reduced pressure to $c a$. $3 \mathrm{~mL}$. The slow addition of $\mathrm{Et}_{2} \mathrm{O}$ led to the precipitation of a yellow-orange solid which was washed with $\mathrm{Et}_{2} \mathrm{O}(3 \times 5 \mathrm{~mL})$ and vacuum-dried.

$\left[\left(\eta^{5}-\mathrm{C}_{5} \mathrm{Me}_{5}\right) \operatorname{Rh}\left(\boldsymbol{\kappa}^{2} \boldsymbol{N}, \mathbf{O}, \boldsymbol{S}-\mathbf{L} 1\right)\right]\left[\mathrm{SbF}_{6}\right] \quad \mathbf{( 6 S b )} . \quad$ Yield: $85 \%$. Anal. calcd for $\mathrm{C}_{20} \mathrm{H}_{27} \mathrm{~F}_{6} \mathrm{NO}_{2} \mathrm{RhSSb} \cdot 2 \mathrm{H}_{2} \mathrm{O}$, \%: C, 33.36; H, 4.34; N, 1.94; S, 4.45. Found, \%: C, 33.60; 
H, 3.90; N, 1.71; S, 4.60. IR (solid, $\left.\mathrm{cm}^{-1}\right): v(\mathrm{C}=\mathrm{O}) 1642$ (s), v( $\left.\mathrm{SbF}_{6}\right) 653$ (s). CD (acetone, $\left.5.0 \times 10^{-4} \mathrm{M}, \mathrm{RT}\right): \lambda, \mathrm{nm},(\Delta \varepsilon): 370(-6.42)$.

$R_{\mathrm{Rh}}, R_{\mathrm{C}}$ diastereomer. ${ }^{1} \mathrm{H} N \mathrm{NMR}\left(300.13 \mathrm{MHz}\right.$, acetone- $\left.\mathrm{d}_{6}, 298 \mathrm{~K}, \mathrm{ppm}\right): \delta 7.49$ - 7.33 (m, 5H, $\mathrm{H}_{\mathrm{Ar}}$ ), $5.70(\mathrm{br}, 1 \mathrm{H}, \mathrm{NH}), 4.82(\mathrm{br}, 1 \mathrm{H}, \mathrm{NH}), 4.16$ (AB system, $J_{\mathrm{AB}}=13.0 \mathrm{~Hz}, 2 \mathrm{H}$,

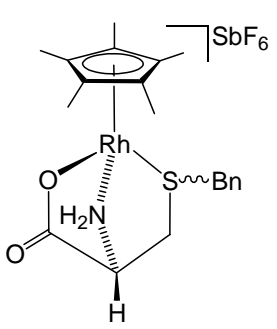
$\mathrm{CH}_{2} \mathrm{Ph}$ ), 3.96 (brs, $1 \mathrm{H}, \mathrm{C}^{*} \mathrm{H}$ ), 2.78 (AB part, $\mathrm{ABX}$ system, $J_{\mathrm{AB}}=14.4$ $\left.\mathrm{Hz}, J_{\mathrm{AX}}=3.7 \mathrm{~Hz}, 2 \mathrm{H}, \mathrm{CH}_{2} \mathrm{C}^{*}\right), 1.91\left(\mathrm{~s}, 15 \mathrm{H}, \mathrm{C}_{5} \mathrm{Me}_{5}\right) .{ }^{13} C\left\{{ }^{1} \mathrm{H}\right\} N M R$ (75.47 MHz, acetone- $\left.d_{6}, 298 \mathrm{~K}, \mathrm{ppm}\right): \delta 175.60(\mathrm{C}=\mathrm{O}), 133.48$, 130.30, 129.11, $128.71\left(6 \mathrm{C}, \mathrm{C}_{\mathrm{Ar}}\right), 97.50\left(\mathrm{~d}, J_{\mathrm{RhC}}=8.2 \mathrm{~Hz}, 5 \mathrm{C}, C_{5} \mathrm{Me}_{5}\right)$, $59.66\left(\mathrm{C}^{*}\right), 39.37\left(\mathrm{CH}_{2} \mathrm{Ph}\right), 31.47\left(\mathrm{CH}_{2} \mathrm{C}^{*}\right), 8.44\left(5 \mathrm{C}, \mathrm{C}_{5} \mathrm{Me}_{5}\right)$.

$\left[\left(\eta^{5}-C_{5} M_{5}\right) \operatorname{Rh}\left(\kappa^{2} N, O, S-L 2\right)\right]\left[S b F_{6}\right] \quad$ (7Sb). Yield: $60 \%$. Anal. calcd for $\mathrm{C}_{21} \mathrm{H}_{29} \mathrm{~F}_{6} \mathrm{NO}_{2}$ RhSSb $\cdot \mathrm{H}_{2} \mathrm{O}$, \%: C, 35.22; H, 4.36; N, 1.96; S, 4.48. Found, \%: C, 35.37; H, 3.97; N, 1.92; S, 4.52. IR (solid, $\left.\mathrm{cm}^{-1}\right): v(\mathrm{C}=\mathrm{O}) 1654$ (s), 1634 (s), v( $\left.\mathrm{SbF}_{6}\right) 651$ (s). $\mathrm{CD}$ (acetone, $\left.4.7 \times 10^{-4} \mathrm{M}, \mathrm{RT}\right): \lambda$, nm, $(\Delta \varepsilon): 374(-3.45)$.

$R_{\mathrm{Rh}}, R_{\mathrm{C}}$ diastereomer (60 \%). ${ }^{1} \mathrm{H}$ NMR (400.16 MHz, acetone-d $\left.\mathrm{d}_{6}, 298 \mathrm{~K}, \mathrm{ppm}\right): \delta 7.50$ 7.33 (m, 5H, $\mathrm{H}_{\mathrm{Ar}}$ ), 5.53 (br, 1H, NH), 5.15 (br, 1H, NH), 4.16 (AB system, $J_{\mathrm{AB}}=13.0$

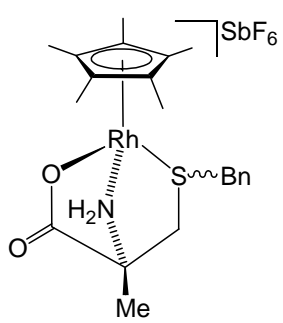
$\mathrm{Hz}, 2 \mathrm{H}, \mathrm{CH}_{2} \mathrm{Ph}$ ), 2.61 (AB system, $J_{\mathrm{AB}}=14.2 \mathrm{~Hz}, 2 \mathrm{H}, \mathrm{CH}_{2} \mathrm{C}^{*}$ ), 1.92 (s, $\left.15 \mathrm{H}, \mathrm{C}_{5} \mathrm{Me}_{5}\right), 1.43$ (s, 3H, C $\left.{ }^{*} \mathrm{Me}\right) .{ }^{13} \mathrm{C}\left\{{ }^{1} \mathrm{H}\right\} N M R(100.6 \mathrm{MHz}$, acetone- $\left.d_{6}, 298 \mathrm{~K}, \mathrm{ppm}\right): \delta 175.91(\mathrm{C}=\mathrm{O}), 133.38,130.36,129.11$, $128.69\left(6 \mathrm{C}, \mathrm{C}_{\mathrm{Ar}}\right), 97.23\left(\mathrm{~d}, J_{\mathrm{RhC}}=8.1 \mathrm{~Hz}, 5 \mathrm{C}, C_{5} \mathrm{Me}_{5}\right), 64.89\left(\mathrm{C}^{*}\right)$, $38.94\left(\mathrm{CH}_{2} \mathrm{Ph}\right), 36.06\left(\mathrm{CH}_{2} \mathrm{C}^{*}\right), 23.57\left(\mathrm{C}^{*} \mathrm{Me}\right), 8.41$ (5C, $\left.\mathrm{C}_{5} M e_{5}\right)$.

$\left[\left(\eta^{5}-C_{5} M_{5}\right) \operatorname{Rh}\left(\kappa^{2} N, O, S-L 3\right)\right]\left[S b F_{6}\right] \quad(8 S b) . \quad$ Yield: $70 \%$. Anal. calcd for $\mathrm{C}_{25} \mathrm{H}_{35} \mathrm{~F}_{6} \mathrm{NO}_{4} \mathrm{RhSSb}$ \%: C, 38.30; H, 4.46; N, 1.79; S, 4.08. Found, \%: C, 38.67; H, 4.38; N, 1.45; S, 3.71. IR (solid, $\left.\mathrm{cm}^{-1}\right): v\left(\mathrm{C}=\mathrm{O}_{\text {Вос }}\right) 1758$ (s), $v(\mathrm{C}=\mathrm{O}) 1614$ (s), $v\left(\mathrm{SbF}_{6}\right)$ 654 (s). CD (acetone, $\left.4.3 \times 10^{-4} \mathrm{M}, \mathrm{RT}\right): \lambda$, nm, $(\Delta \varepsilon): 377(-1.97)$. 
$R_{\mathrm{Rh}}, R_{\mathrm{C}}$ diastereomer (85 \%). ${ }^{1} \mathrm{H} N \mathrm{NR}\left(400.16 \mathrm{MHz} \text {, acetone- } \mathrm{d}_{6}, 230 \mathrm{~K}, \mathrm{ppm}\right)^{\mathrm{a}}: \delta 7.87$ (brs, 1H, NH), 7.50 - 7.35 (m, 5H, $\mathrm{H}_{\mathrm{Ar}}$ ), 4.31 (AB system, $J_{\mathrm{AB}}=14.8 \mathrm{~Hz}, 2 \mathrm{H}, \mathrm{CH}_{2} \mathrm{Ph}$ ),

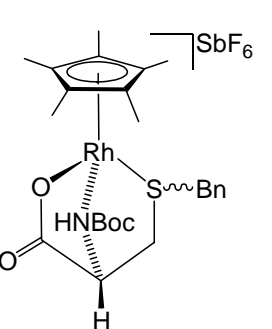

4.16 (brs, 1H, C $\left.{ }^{*} \mathrm{H}\right), 2.62\left(\mathrm{AB}\right.$ part, ABX system, $J_{\mathrm{AB}}=13.0 \mathrm{~Hz}, J_{\mathrm{AX}}$ $\left.=3.2 \mathrm{~Hz}, 2 \mathrm{H}, \mathrm{CH}_{2} \mathrm{C}^{*}\right), 1.88\left(\mathrm{~s}, 15 \mathrm{H}, \mathrm{C}_{5} \mathrm{Me}_{5}\right), 1.56$ (s, 9H, $\mathrm{Me}_{t \mathrm{Bu}}$ ). ${ }^{13} \mathrm{C}\left\{{ }^{1} \mathrm{H}\right\}$ NMR (125.8 MHz, acetone-d $\left.6,230 \mathrm{~K}, \mathrm{ppm}\right): \delta 176.77$ $(\mathrm{C}=\mathrm{O}), 156.73\left(\mathrm{C}=\mathrm{O}_{\mathrm{Boc}}\right), 132.82,130.77,129.30,128.95\left(6 \mathrm{C}, \mathrm{C}_{\mathrm{Ar}}\right)$,

$98.41\left(\mathrm{~d}, J_{\mathrm{RhC}}=8.0 \mathrm{~Hz}, 5 \mathrm{C}, C_{5} \mathrm{Me}_{5}\right), 86.87\left(\mathrm{C}_{t \mathrm{Bu}}\right), 62.76\left(\mathrm{C}^{*}\right), 38.21\left(\mathrm{CH}_{2} \mathrm{Ph}\right), 27.30$ (3C, $\left.\mathrm{Me}_{t \mathrm{Bu}}\right), 26.77\left(\mathrm{CH}_{2} \mathrm{C}^{*}\right), 8.60$ (5C, $\left.\mathrm{C}_{5} \mathrm{Me}_{5}\right)$.

\section{Preparation of the complex $\left[\left(\eta^{5}-\mathrm{C}_{5} \mathrm{Me}_{5}\right) \mathrm{Rh}\left(\kappa^{3} N, O, S-\mathrm{L} 3_{-\mathrm{H}}\right)\right](9)$}

At room temperature, to a suspension of $127.9 \mathrm{mg}(0.17 \mathrm{mmol})$ of $\mathbf{8 S b}, 14.3 \mathrm{mg}(0.17$ mmol) of $\mathrm{NaHCO}_{3}$ were added. The suspension was vigorously stirred for $3 \mathrm{~h}$ and then was concentrated under reduced pressure until dryness. The residue was extracted with $\mathrm{CH}_{2} \mathrm{Cl}_{2}(4 \times 5 \mathrm{~mL})$ and the resulting solution was concentrated under reduced pressure to $c a .1 \mathrm{~mL}$. The slow addition of $n$-hexane led to the precipitation of an orange solid which was washed with $n$-hexane $(4 \times 5 \mathrm{~mL})$ and vacuum-dried. Yield: $80 \%$. Alternatively, complex 9 can be prepared as follows: At RT, to a suspension of the dimer $\left[\left\{\left(\eta^{5}-\mathrm{C}_{5} \mathrm{Me}_{5}\right) \mathrm{RhCl}_{2}(\mu-\mathrm{Cl})_{2}\right](200.2 \mathrm{mg}, 0.32 \mathrm{mmol})\right.$, in $10 \mathrm{~mL}$ of $\mathrm{MeOH}, 201.5$ mg (0.64 mmol) of HL3 were added. The resulting orange solution was stirred for 15 min and then $108.7 \mathrm{mg}(1.29 \mathrm{mmol})$ of $\mathrm{NaHCO}_{3}$ were added. The resulting suspension was vigorously stirred for $2 \mathrm{~h}$ and then was concentrated under reduced pressure until dryness. The residue was extracted with $\mathrm{CH}_{2} \mathrm{Cl}_{2}(4 \times 5 \mathrm{~mL})$ and the resulting solution was concentrated under reduced pressure to ca. $3 \mathrm{~mL}$. The slow addition of $n$-hexane led to the precipitation of an orange solid which was washed with $n$-hexane $(4 \times 5 \mathrm{~mL})$ and vacuum-dried. Yield: $85 \%$. 
Anal. calcd for $\mathrm{C}_{25} \mathrm{H}_{34} \mathrm{NO}_{4} \mathrm{RhS}$, \%: C, 54.84; H, 6.26; N, 2.56; S, 5.86. Found, \%: C, 54.44; H, 6.09; N, 2.46; S, 5.44. IR (solid, $\mathrm{cm}^{-1}$ ): v(C=O) 1627 (s), 1621 (s). CD (acetone, $\left.4.0 \times 10^{-4} \mathrm{M}, \mathrm{RT}\right): \lambda$, $\mathrm{nm},(\Delta \varepsilon): 342(-5.54)$.

$R_{\mathrm{Rh}}, R_{\mathrm{C}}$ diastereomer. ${ }^{1} \mathrm{H} N \mathrm{NM}\left(300.13 \mathrm{MHz}, \mathrm{CDCl}_{3}, 298 \mathrm{~K}, \mathrm{ppm}\right): \delta 7.42$ - 7.29 (m, 5H, $\mathrm{H}_{\mathrm{Ar}}$ ), $4.68\left(\mathrm{br}, 1 \mathrm{H}, \mathrm{C}^{*} \mathrm{H}\right.$ ), 3.95 (AB system, $\left.J_{\mathrm{AB}}=13.4 \mathrm{~Hz}, 2 \mathrm{H}, \mathrm{CH}_{2} \mathrm{Ph}\right), 2.15$ (br, $2 \mathrm{H}$,

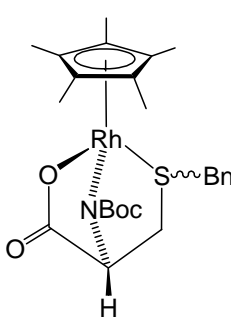

$\left.\mathrm{CH}_{2} \mathrm{C}^{*}\right), 1.90$ (s, 15H, $\left.\mathrm{C}_{5} \mathrm{Me}_{5}\right), 1.41$ (s, 9H, $\left.\mathrm{Me}_{t \mathrm{Bu}}\right) .{ }^{13} \mathrm{C}\left\{{ }^{1} \mathrm{H}\right\} \mathrm{NMR}(75.47$

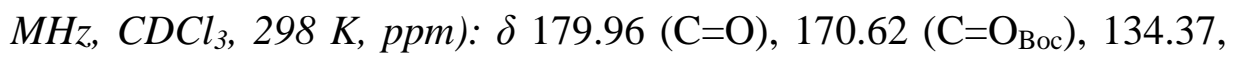
129.94, 129.05, $128.33\left(6 \mathrm{C}, \mathrm{C}_{\mathrm{Ar}}\right), 95.62\left(\mathrm{~d}, J_{\mathrm{RhC}}=8.3 \mathrm{~Hz}, 5 \mathrm{C}, C_{5} \mathrm{Me}_{5}\right)$, $81.54\left(\mathrm{C}_{t \mathrm{Bu}}\right), 67.72\left(\mathrm{C}^{*}\right), 40.17\left(\mathrm{CH}_{2} \mathrm{Ph}\right), 32.89\left(\mathrm{CH}_{2} \mathrm{C}^{*}\right), 28.78$ (3C, $\left.\mathrm{Me}_{t \mathrm{Bu}}\right) 9.56\left(5 \mathrm{C}, \mathrm{C}_{5} \mathrm{Me}_{5}\right)$.

\section{Crystal Structure Determination of Complexes 6Sb, 7Sb, and 9}

X-Ray diffraction data were collected at 100(2)K with graphite-monochromated Mo Ka radiation $\left(\lambda=0.71073 \AA\right.$ ) using narrow $\omega$ rotations $\left(0.3^{\circ}\right)$ on a Bruker APEX DUO diffractometer. Intensities were integrated and corrected for absorption effects with SAINT-PLUS ${ }^{25}$ and SADABS ${ }^{26}$ programs for complexes $\mathbf{6 S b}$ and $\mathbf{9}$, and with CELL_NOW ${ }^{27}$ and TWINABS ${ }^{28}$ programs for twinned crystal of complex 7Sb.

The structures were solved by direct methods with SHEXLS- $2013^{29}$ and refined by full-matrix least-squares refinement on $F^{2}$ with SHELXL-2014. ${ }^{30}$ The absolute configuration was determined on the basis of the previously known internal references, and this assignment was confirmed using the Flack parameter. ${ }^{31}$ Experimental and crystal data are summarized in Table 3. Specific refinement details are shown below.

Crystal data for $\mathbf{6 S} \boldsymbol{b}$ : Four fluorine atoms of $\mathrm{SbF}_{6}$ counterion have been found to be disordered. They have been included in the model in two sets of positions and isotropically refined with complementary occupancy factors (0.54/0.46(1)). H12, H13A, 
H13B and hydrogen atoms bonded to nitrogen atom and to the oxygen atom of $\mathrm{MeOH}$ solvent have been included in the model in observed positions. Some geometrical restraints in bond lengths have been used in their refinement.

Table 3. Experimental and crystal data for $\mathbf{6 S b}, \mathbf{7 S b}$ and $\mathbf{9}$ complexes.

\begin{tabular}{|c|c|c|c|}
\hline & $6 \mathrm{Sb}$ & $7 \mathrm{Sb}$ & 9 \\
\hline Formula & $\mathrm{C}_{20} \mathrm{H}_{27} \mathrm{~F}_{6} \mathrm{NO}_{2} \mathrm{RhSSb} \cdot \mathrm{CH}_{4} \mathrm{O}$ & $\mathrm{C}_{21} \mathrm{H}_{29} \mathrm{~F}_{6} \mathrm{NO}_{2} \mathrm{RhSSb}$ & $\mathrm{C}_{25} \mathrm{H}_{34} \mathrm{NO}_{4} \mathrm{RhS}$ \\
\hline $\mathrm{M}$ & 716.19 & 698.17 & 547.50 \\
\hline Crystal habit & Yellow prism & yellow needle & orange needle \\
\hline Dimensions $\left(\mathrm{mm}^{3}\right)$ & $0.153 \times 0.212 \times 0.318$ & $0.058 \times 0.094 \times 0.317$ & $0.067 \times 0.136 \times 0.216$ \\
\hline Crystal system & Orthorhombic & monoclinic & orthorhombic \\
\hline Space group & $P 22_{1} 2_{1} 2_{1}$ & $P 2_{1}$ & $P 22_{1} 2$ \\
\hline Unit cell $\left(\AA,{ }^{\circ}\right)$ & $\begin{array}{l}a=9.0609(4) \\
b=12.3624(5) \\
c=22.9088(9)\end{array}$ & $\begin{array}{l}a=12.326(3) \\
b=11.038(3) \\
c=19.034(5) \\
\beta=103,541(4)\end{array}$ & $\begin{array}{l}a=17.4802(10) \\
b=19.3568(11) \\
c=7.4057(4)\end{array}$ \\
\hline$Z$ & 4 & 4 & 4 \\
\hline$V\left(\AA^{3}\right)$ & $2566.12(18)$ & 2517.8(11) & $2505.8(2)$ \\
\hline$D_{c}\left(\mathrm{~g} / \mathrm{cm}^{3}\right)$ & 1.854 & 1.842 & 1.451 \\
\hline$\mu\left(\mathrm{mm}^{-1}\right)$ & 1.844 & 1.874 & 0.795 \\
\hline $\mathrm{T}_{\min } / \mathrm{T}_{\max }$ & $0.573 / 0.717$ & $0.465 / 0.602$ & $0.539 / 0.928$ \\
\hline $2 \theta_{\max }\left({ }^{\circ}\right)$ & 59.16 & 41.4 & 58.93 \\
\hline Refs. collected/uniques & $26945 / 6682$ & $29233 / 9393$ & $19421 / 6432$ \\
\hline$R_{\text {int }}$ & 0.0398 & 0.0956 & 0.0713 \\
\hline Data/restraints/parameters & $6682 / 4 / 334$ & $9393 / 1 / 360$ & $6432 / 1 / 300$ \\
\hline$R_{1}$ [reflections $\left.I>2 \sigma(I)\right]$ & 0.0312 [6562] & $0.0606[7326]$ & $0.0434[5536]$ \\
\hline wR2 [all data] & 0.0745 & 0.1269 & 0.1064 \\
\hline GoF & 1.155 & 1.046 & 0.985 \\
\hline Flack parameter & $-0.015(13)$ & $0.04(3)$ & $-0.07(3)$ \\
\hline Largest diff. peak $\left(\mathrm{e} . \AA^{-3}\right)$ & 0.960 & 0.943 & 0.703 \\
\hline
\end{tabular}

Crystal data for $\mathbf{7 S b}$ : The crystal selected for data collection did not show relevant intensity over $\theta=24.7^{\circ}$. Moreover, an analysis of the preliminary data pointed out the existence of a twin, with two detected components, with main contribution associated to one domain (twin ratio $0.879 / 0.121$ ). In order to properly separate the contributions of both domains and to minimize the noise, data integration has been performed 
considering both components, to a maximal resolution of $\theta=21^{\circ}$. This restriction prevents an adequate refinement of the anisotropic displacement parameters for the lighter atoms, unless a large number of bonding restrains were included. Eventually, we decided to consider only Rh, Sb, S and non-disordered $\mathrm{F}$ atoms to have anisotropic atomic displacement parameters.

Fluorine atoms of a $\mathrm{SbF}_{6}$ counterion have been found to be disordered. When convergence is achieved, five residual density peaks are found in intermolecular regions. Attempts to interpret them as water solvent molecules do not improve the model, as they are too close to methylic hydrogen atoms of $\eta^{5}-\mathrm{C}_{5} \mathrm{Me}_{5}$ fragments.

Crystal data for 9: The $\left(\eta^{5}-\mathrm{C}_{5} \mathrm{Me}_{5}\right)$ group and a methyl fragment have been found to be disordered. Hydrogen H12 has been included in the model in observed position and freely refined.

\section{Computational details}

The DFT calculations were carried out with the Gaussian 09 software package, ${ }^{32}$ optimizing the structures using the b3-lyp hybrid functional and the basis set LanL2DZ for rhodium atoms and 6-31G(d,p) for the remaining ones. ${ }^{33}$ All minima (no imaginary frequencies) and transition states (one imaginary frequency) were characterized by calculating the Hessian matrix. The transition state search was performed with a relaxed PES scan of the key geometrical parameter and then the highest energy structure was optimized as a transition state by the default Gaussian 09 algorithms. The chemical correctness of the transition states found were confirmed by visual inspection of the normal mode having a negative vibrational frequency, followed by moving the TS geometries along the reaction path using the GaussView program utilities and reoptimizing to verify the nature of the products. 
The energetics of the epimerization mechanism is discussed based on the relative Gibbs free energy with respect to the infinitely separated reactants. All reported free energies involve ZPE and gas-phase thermal corrections (entropy and enthalpy, 298.15 $\mathrm{K}, 1 \mathrm{~atm})$ and the conductor-like polarizable continuum model approach (CPCM) implemented in the Gaussian 09 software was used in the final single point calculations on the above gas-phase optimized geometries to incorporate the solvent effect of methanol in the thermodynamic data.

\section{Acknowledgments}

We thank the Ministerio de Economía y Competitividad of Spain (CTQ2012-32095, CTQ2014-53033-P, CTQ2015-67366-P and CTQ2013-408555R) and Gobierno de Aragón and European Social Fund (Grupos Consolidados: Catalizadores Organometálicos Enantioselectivos, Aminoácidos y Péptidos and Inorganic Molecular Architecture) for financial support. This work was supported by the CONSOLIDER INGENIO 2010 program under the project “Factoría de Cristalización” (CSD20060015). M. C. acknowledges Diputación General de Aragón, CSIC and European Social Fund for a grant. R. R. and P. G. O. acknowledge CSIC, European Social Fund and Ministerio de Economía y Competitividad of Spain for a JAE and a Ramón y Cajal (RYC-2013-13800) grants and for a PTA contract, respectively. We thank the Centro de Supercomputación de Galicia (CESGA) for generous allocation of computational resources. 


\section{Notes and references}

1 (a) J. Paradowska, M. Stodulski and J. Mlynarski, Angew. Chem. Int. Ed. 2009, 48, 4288-4297. (b) Comprehensive Coordination Chemistry II, J. A. McCleverty and T. J. Meyer, Eds.; Elsevier Science, 2003. (c) J. Chin, S.-S. Lee, K.-J. Lee, S. Park and D. H. Kim, Nature 1999, 401, 254-257. (d) K. Severin, R. Bergs and W. Beck, Angew. Chem. Int. Ed. 1998, 37, 1635-1654. (e) T. G. Appleton, Coord. Chem. Rev. 1997, 166, 313-359. (f) N. Paulic and N. Raos, J. Coord. Chem. 1994, 31, 181-190. (g) A. Iakovidis and N. Hadjiliadis, Coord. Chem. Rev. 1994, 135/136, 17-63. (h) H. Kozlowski and L. D. Pettit, In Chemistry of the Platinum Group Metals; Hartley, F. R., Ed.; Elsevier: New York, 1991; Chapter 15, p 530. (i) S. H. Laurie, In Comprehensive Coordination Chemistry; Wilkinson, G., Ed.; Pergamon: Oxford, 1987; Vol. 2, Chapter 20.2, p 739-776. (j) A. A. Ioganson, Russ. Chem. Rev. 1985, 54, 277-292. (k) L. D. Pettit and M. Bezer, Coord. Chem. Rev. 1985, 61, 97-114.

2 F. A. Egbewande, L. E. H. Paul, B. Therrien and J. Furrer, Eur. J. Inorg. Chem. 2014, 1174-1184.

3 K. Micskei, T. Patonay, L. Caglioti and G. Palyi, Chem. Biodiv. 2010, 7, 16601669.

4 See for example: (a) L. E. H. Paul, B. Therrien and J. Furrer, Inorg. Chem. 2012, 51, 1957-1067. (b) F. Wang, H. Chen, J. A. Parkinson, P. del S. Murdoch and P. J. Sadler, Inorg. Chem. 2002, 41, 4509-4523.

5 (a) A. Igashira-Kamiyama and T. Konno, Dalton Trans. 2011, 40, 7249-7263. (b) T. Aridomi, K. Takamura, A. Igashira-Kamiyama, T. Kawamoto and T. Konno, Chem. Eur. J. 2008, 14, 7752-7755. 
6 S. Niu, W. Lv, G. Zhou, Y. He, B. Li, Q.-H. Yang and F. Kang, Chem. Commun. 2015, 51, 17720-17723.

$7 \quad$ X. Chen, Y. Zhou, X. Peng and J. Yoon, Chem. Soc. Rev. 2010, 39, 2120-2135.

8 (a) O. Gordon, T. V. Slenters, P. S. Brunetto, A. E. Villaruz, D. E. Sturdevant, M. Otto, R. Landmann and K. M. Fromm, Antimicrob. Agents Chemother. 2010, 54, 4208-4218. (b) S. Y. Liau, D. C. Read, W. J. Pugh, J. R. Furr and A. D. Russell, Lett. Appl. Microbiol. 1997, 25, 279-283.

9 C. Darnault, A. Volbeda, E. J. Kim, P. Legrand, X. Vernède, P. A. Lindahl and J. C. Fontecilla-Camps, Nat. Struct. Biol. 2003, 10, 271-279.

10 A. Volbeda, M. H. Charon, C. Piras, E. C. Hatchikian, M. Frey and J. C. Fontecilla-Camps, Nature 1995, 373, 580-587.

11 J. Patalenszki, L. Biró, A. C. Bényei, T. R. Muchova, J. Kasparkova and P. Bublyó, RSC Adv. 2015, 5, 8094-8107.

12 C. Cativiela and M. Ordoñez, Tetrahedron Asymmetry 2009, 20, 1-63, and references therein.

13 D. Pattenden, S. M. Thom and M. F. Jones, Tetrahedron 1993, 49, 2131-2138.

14 Y. Jia, X. Dong, P. Zhou, X. Liu, L. Pan, H. Xin, Y. Z. Zhu and Y. Wang, Eur. J. Med. Chem. 2012, 55, 176-187.

15 J. W. Kang, K. Moseley and P. M. Maitlis, J. Am. Chem. Soc. 1969, 91, 59705977.

16 Alternatively, complex $\mathbf{3}$ can be prepared by treating with HL1 the acetylacetonate [( $\left.\left.\eta^{5}-\mathrm{C}_{5} \mathrm{Me}_{5}\right) \mathrm{RhCl}(\mathrm{acac})\right]$ (W. Rigby, H.-B. Lee, P. M. Bailey, J. A. McCleverty and P. M. Maitlis, J. Chem. Soc., Dalton Trans. 1979, 387-394). 
17 All the trials give rise to twin and weakly diffracting crystals. Eventually a set of data was tentatively measured. F. J. Lahoz, P. García-Orduña,. CSD Communication to the Cambridge Structural Database, CCDC: Cambridge, UK, 2016. deposition number CCDC 1485793.

18 (a) R. S. Cahn, C. Ingold and V. Prelog, Angew. Chem., Int. Ed. Engl. 1966, 5, 385-415. (b) V. Prelog and G. Helmchen, Angew. Chem., Int. Ed. Engl. 1982, 21, 567-583. (c) C. Lecomte, Y. Dusausoy, J. Protas, J. Tirouflet and A. Dormond, J. Organomet. Chem. 1974, 73, 67-76.

19 K. Nakamoto, Infrared and Raman Spectra of Inorganic and Coordination Compounds, 4th ed.; Wiley-Interscience: New York, 1986.

20 NMR analyses of aliquots show that the diastereomeric composition does not change importantly over the reaction time. These measured compositions matches up with the one that was determined for the isolated solid.

21 The ${ }^{15} \mathrm{~N}$ NMR data were obtained through ${ }^{1} \mathrm{H}-{ }^{15} \mathrm{~N}$ HMQC experiments.

22 D. Carmona, F. J. Lahoz, R. Atencio, L. A. Oro, M. P. Lamata, F. Viguri, E. San José, C. Vega, J. Reyes, F. Joó and A. Kathó, Chem. Eur. J. 1999, 5, 1544-1564.

23 Most of the compounds crystallize with variable amounts of water which are detected by ${ }^{1} \mathrm{H}$ NMR spectroscopy.

24 The microanalyses quoted for complexes $\mathbf{3}$ and $\mathbf{4}$ correspond to mixtures of $\mathbf{3}$ and $\mathbf{6 C l}$ and of $\mathbf{4}$ and $\mathbf{7 C l}$, respectively.

25 SAINT+, version 6.01: Area-Detector Integration Software, Bruker AXS, Madison, WI, 2001.

26 (a) R. H. Blessing, Acta Crystallogr. 1995, A51, 33-38. (b) SADABS, Area Detector Absorption Correction Program, Bruker AXS, Madison, WI, 1996. 
27 G. M. Sheldrick, CELL_NOW, University of Göttingen, Germany, 2008.

28 G. M. Sheldrick, TWINABS, University of Göttingen, Germany, 2008.

29 (a) G. M. Sheldrick, Acta Crystallogr. 1990, A46, 467-473. (b) G. M. Sheldrick, Acta Crystallogr. 2008, A64, 112-122.

30 G. M. Sheldrick, Acta Crystallogr. 2015, C71, 3-8.

31 H. D. Flack, Acta Crystallogr. 1983, A39, 876-881.

32 M. J. Frisch, et al. Gaussian 09 (Revision D.01); Gaussian, Inc., Wallingford, CT, 2009.

33 (a) C. Lee, W. Yang and R. G. Parr, Phys. Rev. B 1988, 37, 785-789. (b) A. D. Becke, J. Chem. Phys. 1993, 98, 1372-1377. (c) A. D. Becke, J. Chem. Phys. 1993, 98, 5648-5652. (d) N. E. Schultz, Y. Zhao and D. G. Truhlar, J. Phys. Chem. A 2005, 109, 11127-11143. 


\section{For table of contents use only}

\section{Half-sandwich complexes of rhodium containing cysteine-derived}

\section{ligands}

María Carmona, Ricardo Rodríguez, Fernando J. Lahoz, Pilar García-Orduña, Iñaki Osante, Carlos Cativiela, José A. López, and Daniel Carmona

${ }^{a}$ Instituto de Síntesis Química y Catálisis Homogénea (ISQCH), CSIC - Universidad de Zaragoza, Departamento de Química Inorgánica, Pedro Cerbuna 12, 50009 Zaragoza, Spain, E-mail: dcarmona@unizar.es,riromar@unizar.es

${ }^{b}$ Instituto de Síntesis Química y Catálisis Homogénea (ISQCH), CSIC - Universidad de Zaragoza, Departamento de Química Orgánica, Pedro Cerbuna 12, 50009 Zaragoza, Spain

Five distinct coordination modes have been disclosed for rhodium complexes containing modified cysteines. From spectroscopic, theoretical and crystallographic data, the absolute configuration of the compounds has been established.

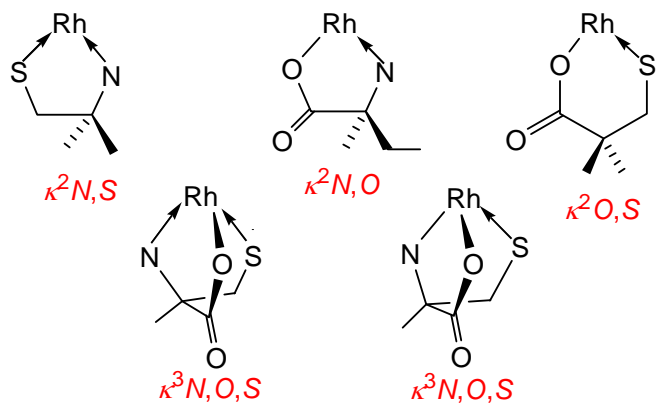

